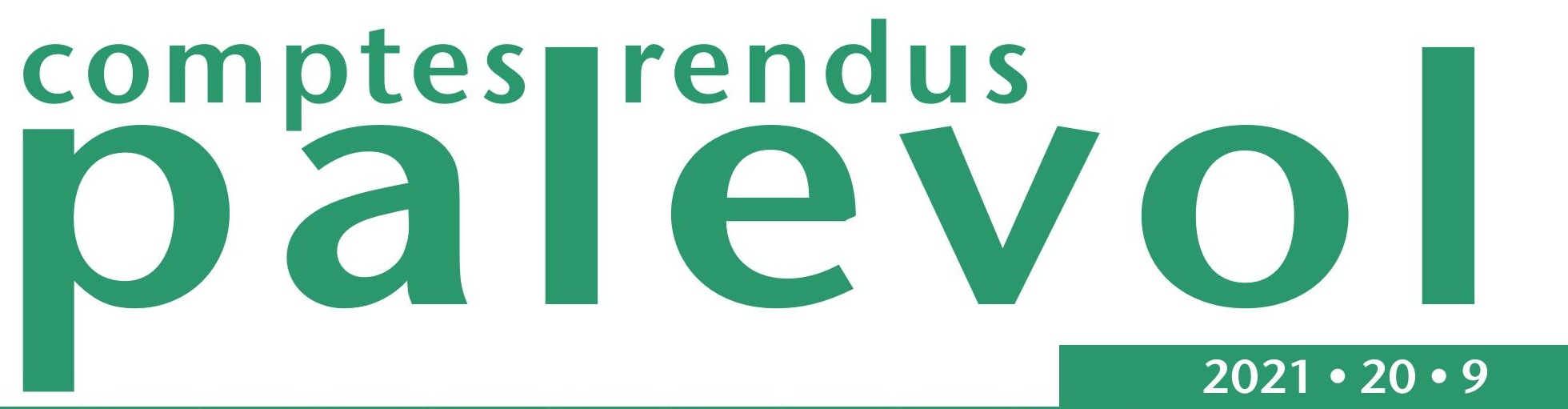

\title{
New skull material of Pleistocene dwarf deer from Crete (Greece)
}

\section{Ann-Marie SCHILLING \& Gertrud E. RÖSSNER}
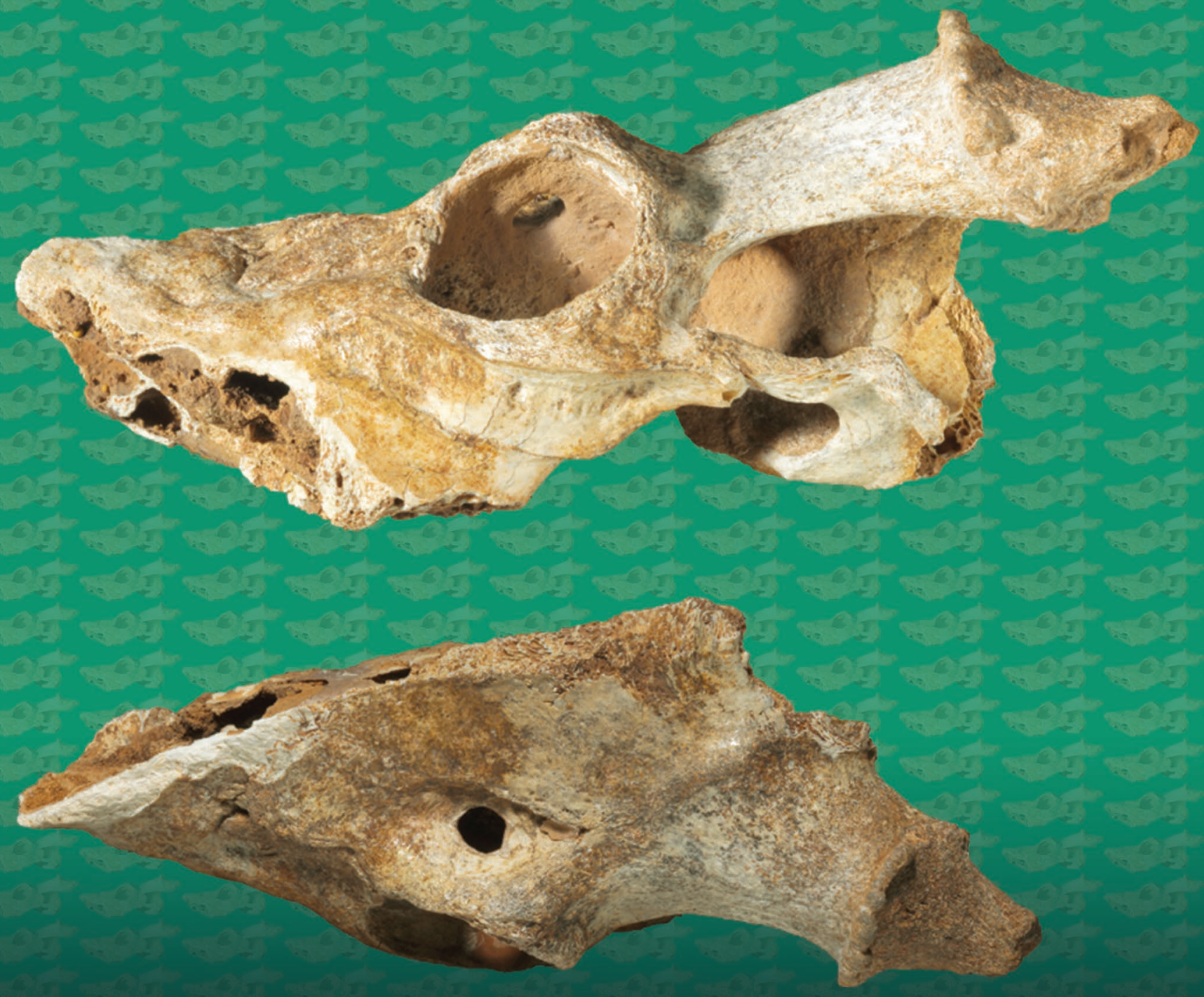
DiRECTEURS de LA PUbLICATION / PUBLICATION DIRECTORS:

Bruno David, Président du Muséum national d'Histoire naturelle

Étienne Ghys, Secrétaire perpétuel de l'Académie des sciences

RÉDACTEURS EN CHEF / EDITORS-IN-CHIEF: Michel Laurin (CNRS), Philippe Taquet (Académie des sciences)

AsSISTANTE DE RÉDACTION / AsSISTANT EDITOR: Adeline Lopes (Académie des sciences; cr-palevol@academie-sciences.fr)

MISE EN PAGE / PAGE LAYOUt: Fariza Sissi \& Audrina Neveu (Muséum national d'Histoire naturelle; fariza.sissi@mnhn.fr)

RÉDACTEURS ASSOCIÉS / ASSOCIATE EDITORS ( ${ }^{*}$, took charge of the editorial process of the article/a pris en charge le suivi éditorial de l'article):

Micropaléontologie/Micropalaeontology

Maria Rose Petrizzo (Università di Milano, Milano)

Paléobotanique/Palaeobotany

Cyrille Prestianni (Royal Belgian Institute of Natural Sciences, Brussels)

Métazoaires/Metazoa

Annalisa Ferretti (Università di Modena e Reggio Emilia, Modena)

Paléoichthyologie/Palaeoichthyology

Philippe Janvier (Muséum national d'Histoire naturelle, Académie des sciences, Paris)

Amniotes du Mésozoïque/Mesozoic amniotes

Hans-Dieter Sues (Smithsonian National Museum of Natural History, Washington)

Tortues/Turtles

Juliana Sterli (CONICET, Museo Paleontológico Egidio Feruglio, Trelew)

Lépidosauromorphes/Lepidosauromorphs

Hussam Zaher (Universidade de São Paulo)

Oiseaux/Birds

Éric Buffetaut (CNRS, École Normale Supérieure, Paris)

Paléomammalogie (mammifères de moyenne et grande taille)/Palaeomammalogy (large and mid-sized mammals)

Lorenzo Rook* (Università degli Studi di Firenze, Firenze)

Paléomammalogie (petits mammifères sauf Euarchontoglires)/Palaeomammalogy (small mammals except for Euarchontoglires)

Robert Asher (Cambridge University, Cambridge)

Paléomammalogie (Euarchontoglires)/Palaeomammalogy (Euarchontoglires)

K. Christopher Beard (University of Kansas, Lawrence)

Paléoanthropologie/Palaeoanthropology

Roberto Macchiarelli (Université de Poitiers, Poitiers)

Archéologie préhistorique/Prehistoric archaeology

Marcel Otte (Université de Liège, Liège)

COUVERTURE / COVER:

Lateral and dorsal views of Candiacervus sp. (photo: Manuela Schellenberger, SNSB-Bayerische Staatssammlung für Paläontologie und Geologie, Germany).

Comptes Rendus Palevol est indexé dans / Comptes Rendus Palevol is indexed by:

- Cambridge Scientific Abstracts

- Current Contents $®$ Physical

- Chemical, and Earth Sciences ${ }^{\circledR}$

- ISI Alerting Services ${ }^{\circledR}$

- Geoabstracts, Geobase, Georef, Inspec, Pascal

- Science Citation Index ${ }^{\circledR}$, Science Citation Index Expanded ${ }^{\circledR}$

- Scopus ${ }^{\circledR}$.

Les articles ainsi que les nouveautés nomenclaturales publiés dans Comptes Rendus Palevol sont référencés par / Articles and nomenclatural novelties published in Comptes Rendus Palevol are registered on:

- ZooBank ${ }^{\circledR}$ (http://zoobank.org)

Comptes Rendus Palevol est une revue en flux continu publiée par les Publications scientifiques du Muséum, Paris et l'Académie des sciences, Paris Comptes Rendus Palevol is a fast track journal published by the Museum Science Press, Paris and the Académie des sciences, Paris

Les Publications scientifiques du Muséum publient aussi / The Museum Science Press also publish:

Adansonia, Geodiversitas, Zoosystema, Anthropozoologica, European Journal of Taxonomy, Naturae, Cryptogamie sous-sections Algologie, Bryologie, Mycologie.

L'Académie des sciences publie aussi / The Académie des sciences also publishes:

Comptes Rendus Mathématique, Comptes Rendus Physique, Comptes Rendus Mécanique, Comptes Rendus Chimie, Comptes Rendus Géoscience, Comptes Rendus Biologies.

Diffusion - Publications scientifiques Muséum national d'Histoire naturelle

CP $41-57$ rue Cuvier F-75231 Paris cedex 05 (France)

Tél. : 33 (0)1 40794805 / Fax: 33 (0)1 40793840

diff.pub@mnhn.fr / https://sciencepress.mnhn.fr

Académie des sciences, Institut de France, 23 quai de Conti, 75006 Paris.

(C) Publications scientifiques du Muséum national d'Histoire naturelle / (C) Académie des sciences, Paris, 2021

ISSN (imprimé / print): 1631-0683/ ISSN (électronique / electronic) : 1777-571X 


\section{New skull material of Pleistocene dwarf deer from Crete (Greece)}

Ann-Marie SCHILLING

Gertrud E. RÖSSNER

SNSB-Bayerische Staatssammlung für Paläontologie und Geologie, Richard-Wagner-Str. 10, 80333 Munich (Germany) and Department of Earth and Environmental Sciences, Ludwig-Maximilians-Universität München, Richard-Wagner-Str. 10, 80333 Munich (Germany)

roessner@snsb.de

schilling.annmarie@gmail.com

Submitted on 7 November 2019 | Accepted on 6 March 2020 | Published on 8 March 2021

KEY WORDS

Candiacervus

craniodental

morphology,

morphometrics,

island evolution.

\section{ABSTRACT}

In the Pleistocene faunas of the island of Crete, Cervidae was one of the most abundant taxa. Respective species vary in body size, including dwarfs, and skeletal morphology; however, the number of species and the identity of the mainland ancestor(s) are still debated. In this paper, we morphologically and morphometrically describe and analyze eight skulls of Cretan deer from a so far little known fossil site near Gerani, Rethymnon, Greece. The recorded character suite allows for affiliation to dwarfed Candiacervus Kuss, 1975, Candiacervus ropalophorus de Vos, 1984 and C. reumeri van der Geer, 2018. It comprises previously unknown unique traits, some of them hinting to sexual dimorphism. Comparisons of the Candiacervus skulls presented here with those of cervids belonging to Megalocerotini Brooke, 1828, s.s. and s.l. stress certain similarities; yet more material is needed to reconstruct Candiacervus' phylogenetic position. The newly detected craniodental specifics allow for more insights into island adaptation of Candiacervus; at the same time, they blur the morphological heritage of their mainland ancestors. 


\section{MOTS CLÉS \\ Candiacervus, \\ morphologie \\ cranio-dentaire, \\ morphométrie, évolution insulaire.}

\begin{abstract}
RÉSUMÉ
Nouveau matériel crânien de cerfs nains du Pléistocène de Crète (Grèce).

Au sein de la faune du Pléistocène de l'île de Crète, les Cervidae sont l'un des taxons les plus abondants. Les différentes espèces se différencient par leur taille, incluant des formes naines, et par la morphologie de leur squelette ; cependant, le nombre d'espèces et l'identité de leur(s) ancêtre(s) continental(aux) sont encore débattus. Dans cet article, nous décrivons et analysons de manière morphologique et morphométrique huit crânes de cerfs crétois d'un site fossilifere peu connu, proche de Gerani, Réthymnon, en Grèce. L'ensemble des caractères observés permet une affiliation aux espèces naines de Candiacervus Kuss, 1975, Candiacervus ropalophorus de Vos, 1984 et C. reumeri van der Geer, 2018. De nouveaux caractères morphologiques uniques sont à relier au dimorphisme sexuel. Les comparaisons de ces crânes de Candiacervus avec ceux d'autres Cervidae appartenant au Megalocerotini Brooke, 1828, s.s. et s.l. pointent des similarités. Cependant, du matériel additionnel est nécessaire pour reconstruire la position phylogénétique de Candiacervus. Les nouvelles données cranio-dentaires permettent un éclairage sur l'adaptation de Candiacervus au milieu insulaire, mais brouillent également l'héritage morphologique de leurs ancêtres continentaux.
\end{abstract}

\section{INTRODUCTION}

Pleistocene fossils from the Mediterranean island of Crete provide a fascinating view into island evolution. Mammals colonized this island during the early Pleistocene, probably by sweepstake route, i.e., swimming, floating, or rafting (Simpson 1940) and the fossil record indicates that the Pleistocene faunas of Crete were highly unbalanced (de Vos 1984), as typical for island faunas (Carlquist 1974; Losos \& Ricklefs 2009). The mammalian fauna of the late middle to late Pleistocene was characterized by giant mice (Mus bateae Mayhew, 1977, M. minotaurus Bate, 1942), the still existent Cretan shrew (Crocidura zimmermanni Wettstein, 1953), a dwarf elephant (Palaeoloxodon creutzburgi (Kuss, 1965)), several species of deer (Candiacervus Kuss, 1975) and an otter (Lutrogale cretensis Symeonides \& Sondaar, 1975) (Strasser et al. 2018).

Cervidae, typically referred to as Candiacervus, are one of the most abundant taxa (Sondaar 1971) in Cretan Pleistocene faunas. Remains of Candiacervus have been found at several sites, mainly in karst caves along the Cretan coastline (Lax 1996; Iliopoulos et al. 2010). Most of the studied material of Candiacervus comes from the Simonelli Cave (Accordi 1972; Malatesta 1980; Caloi \& Palombo 1995; Palombo et al. 2008), the Bate Cave (Raia \& Meiri 2006; Kolb et al. 2015), the Liko Cave, and the Gerani caves (de Vos 1984; Raia \& Meiri 2006; van der Geer et al. 2006a, b, c, 2014; Vislobokova 2013; Kolb et al. 2015; van der Geer 2018). Post-cranial and cranial remains, including antlers, as well as dental remains have been obtained from these sites (see references given above and also Simonelli 1908; Kuss 1965, 1975; de Vos 1979; Capasso Barbato \& Petronio 1986), and were dated to the late Pleistocene.

Post-cranial material of Candiacervus has been utilized to investigate, among other aspects, bone growth and skeletal adaptations to the palaeoenvironment, as well as for comparative studies (Caloi \& Palombo 1990; van der Geer et al. 2006b; van der Geer 2008, 2014; Attard \& Reumer 2009;
Mazza 2013; Kolb et al. 2015; Amson \& Kolb 2016; Mazza et al. 2016). Moreover, size differences of post-cranial remains have been interpreted to indicate the existence of six distinct size groups (cf. de Vos 1979, 1984) ranging from about $40 \mathrm{~cm}$ to $165 \mathrm{~cm}$ height at withers (de Vos 1979; van der Geer et al. 2006a). Analyses of skull specimens (see de Vos 1984) and of antlers (van der Geer 2018 and references therein) allowed the distinction of four types, referred to as skull types a-d by de Vos (1984). Up to now, it has not been possible to unambiguously link post-cranial with cranial remains, including antlers. However, de Vos (1984: 46) presented a well-reasoned suggestion "that there are at least eight groups of fossil deer [on Crete], each one representing a species". He maintained the view that all of these belonged to one genus, Candiacervus, and referred to them, from smallest to largest, as Candiacervus ropalophorus de Vos, 1984, Candiacervus sp. IIa, IIb, and IIc, Candiacervus cretensis (Simonelli, 1908), Candiacervus rethymnensis Kuss, 1975, Candiacervus sp. V, and Candiacervus sp. VI , respectively (Table 1 ).

In contrast, Capasso Barbato \& Petronio (1986) and Capasso Barbato $(1989,1990)$ argued in favor of five distinct species (Table 1), which they assigned to two different genera. According to their classification: 1) Candiacervus ropalophorus de Vos, 1984 and Candiacervus sp. IIa, IIb, and IIc are conspecific - Megaceros (Candiacervus) ropalophorus (de Vos, 1984) - later referred to as Megaloceros (Candiacervus) ropalophorus; 2) Candiacervus cretensis (Simonelli, 1908) was revised as Megaceroides (Candiacervus) cretensis (Simonelli, 1908). Candiacervus rethymnensis Kuss, 1975 as well as the larger species Candiacervus dorothensis (Capasso Barbato, 1990) and Candiacervus major (Capasso Barbato \& Petronio, 1986), were revised to belong to a newly established subgenus of Cervus (Leptocervus) Capasso Barbato, 1990, and classified into; 3) Cervus (Leptocervus) rethymnensis (Kuss, 1975); 4) Cervus (Leptocervus) dorothensis Capasso Barbato, 1990; and 5) Cervus (Leptocervus) major Capasso Barbato \& Petronio, 1986, respectively. In a more recent publication, Capasso 
TABLE 1. - Diversity and taxonomical history of Cretan deer.

\begin{tabular}{|c|c|c|c|c|c|c|c|c|c|}
\hline \multirow{2}{*}{$\begin{array}{l}\text { Morphotype } \\
\text { or "species" } \\
\text { (de Vos } \\
1979,1984 \text { ) } \\
\end{array}$} & \multirow[b]{2}{*}{$\begin{array}{l}\text { Available } \\
\text { material }\end{array}$} & \multirow[b]{2}{*}{$\begin{array}{l}\text { Description } \\
\text { based on } \\
\text { element }\end{array}$} & \multirow[b]{2}{*}{$\begin{array}{l}\text { Type } \\
\text { material }\end{array}$} & \multirow[b]{2}{*}{$\begin{array}{l}\text { Type } \\
\text { locality }\end{array}$} & \multirow[b]{2}{*}{ Other occurrences } & \multicolumn{4}{|c|}{ Revision } \\
\hline & & & & & & $\begin{array}{l}\text { Capasso } \\
\text { Barbato } \\
(1990) \\
\end{array}$ & $\begin{array}{l}\text { Capasso } \\
\text { Barbato } \\
(1995) \\
\end{array}$ & $\begin{array}{l}\text { Caloi \& } \\
\text { Palombo } \\
(1996)\end{array}$ & $\begin{array}{l}\text { van der Geer } \\
(2018)\end{array}$ \\
\hline $\begin{array}{l}\text { Candiacervus } \\
\text { ropalophorus } \\
\text { de Vos, 1984; } \\
\text { Size group } 1\end{array}$ & cranial & skulls & $\begin{array}{l}\text { male skull, } \\
\text { Ge4-46, } \\
\text { holotype } \\
\text { (de Vos 1984, } \\
\text { plate. 10) }\end{array}$ & $\begin{array}{l}\text { Gerani 4, } \\
\text { uppermost } \\
40 \mathrm{~cm}\end{array}$ & $\begin{array}{l}\text { Gerani 2,3,6; Mavro } \\
\text { Mouri 4c; Sourida, } \\
\text { Simonelli Cave, } \\
\text { Rethymnon fissure; } \\
\text { Kalo Chorafi }\end{array}$ & $\begin{array}{l}\text { Megaceros } \\
\text { (Candiacervus) } \\
\text { ropalophorus }\end{array}$ & $\begin{array}{l}\text { Megaceroides } \\
\text { (Candiacervus) } \\
\text { ropalophorus }\end{array}$ & $\begin{array}{l}\text { Megaceroides } \\
\text { (Candiacervus) } \\
\text { "ropalophorus" }\end{array}$ & $\begin{array}{l}\text { Candiacervus } \\
\text { ropalophorus }\end{array}$ \\
\hline- & $\begin{array}{l}\text { post- } \\
\text { cranial }\end{array}$ & $\begin{array}{l}\text { metacarpi, } \\
\text { metatarsi }\end{array}$ & - & - & $\begin{array}{l}\text { Gerani 4, } \\
\text { Rethymnon fissure }\end{array}$ & - & - & - & - \\
\hline $\begin{array}{l}\text { Candiacervus } \\
\text { sp. Ila; } \\
\text { Size group } 2\end{array}$ & cranial & $\begin{array}{l}\text { skulls, } \\
\text { antlers }\end{array}$ & $\begin{array}{l}\text { male skull, } \\
\text { AMPG(V) } \\
\text { 1734, holotype } \\
\text { (de Vos 1984, } \\
\text { plate 12) }\end{array}$ & $\begin{array}{l}\text { Liko, } \\
\text { uppermost } \\
75 \mathrm{~cm}\end{array}$ & $\begin{array}{l}\text { Gerani 1, 2, 4; Grida } \\
\text { Avlaki; Gumbes } \\
\text { B; Kalo Chorafi; } \\
\text { Mavromuri } 3 \text { and 4; } \\
\text { Peristeri 2, Sifanos, } \\
\text { Simonelli Cave }\end{array}$ & $\begin{array}{l}\text { Megaceros } \\
\text { (Candiacervus) } \\
\text { ropalophorus }\end{array}$ & $\begin{array}{l}\text { Megaceroides } \\
\text { (Candiacervus) } \\
\text { ropalophorus }\end{array}$ & $\begin{array}{l}\text { Megaceroides } \\
\text { (Candiacervus) } \\
\text { "ropalophorus" }\end{array}$ & $\begin{array}{l}\text { Candiacervus } \\
\text { listeri }\end{array}$ \\
\hline $\begin{array}{l}\text { Candiacervus } \\
\text { sp. Ilc; } \\
\text { Size group } 2\end{array}$ & cranial & $\begin{array}{l}\text { skulls, } \\
\text { antlers }\end{array}$ & $\begin{array}{l}\text { AMPG(V) } \\
\text { 1736, holotype } \\
\text { (de Vos 1984, } \\
\text { plate 14) }\end{array}$ & $\begin{array}{l}\text { Liko, } \\
\text { uppermost } \\
75 \mathrm{~cm}\end{array}$ & $\begin{array}{l}\text { Peristeri 2; Simonelli } \\
\text { Cave; Kalo Chorafi; } \\
\text { Mavromuri } 3\end{array}$ & $\begin{array}{l}\text { Megaceros } \\
\text { (Candiacervus) } \\
\text { ropalophorus }\end{array}$ & $\begin{array}{l}\text { Megaceroides } \\
\text { (Candiacervus) } \\
\text { ropalophorus }\end{array}$ & $\begin{array}{l}\text { Megaceroides } \\
\text { (Candiacervus) } \\
\text { "ropalophorus" }\end{array}$ & $\begin{array}{l}\text { Candiacervus } \\
\text { reumeri }\end{array}$ \\
\hline $\begin{array}{l}\text { Candiacervus } \\
\text { cretensis } \\
\text { (Simonelli, } \\
\text { 1908); } \\
\text { Size group } 3\end{array}$ & Cranial & $\begin{array}{l}\text { skulls, } \\
\text { antlers }\end{array}$ & - & Gerani 4 & Simonelli cave & $\begin{array}{l}\text { Megaceros } \\
\text { (Candiacervus) } \\
\text { cretensis }\end{array}$ & $\begin{array}{l}\text { Megaceros } \\
\text { (Candiacervus) } \\
\text { cretensis }\end{array}$ & $\begin{array}{l}\text { Megaceroides } \\
\text { (Candiacervus) } \\
\text { cretensis }\end{array}$ & $\begin{array}{l}\text { Candiacervus } \\
\text { cretensis }\end{array}$ \\
\hline- & $\begin{array}{l}\text { post- } \\
\text { cranial }\end{array}$ & $\begin{array}{l}\text { right } \\
\text { metacarpal }\end{array}$ & $\begin{array}{l}\text { metacarpal, } \\
\text { lectotype } \\
\text { (Simonelli } \\
\text { 1908, fig. } \\
24,25 \text { ) }\end{array}$ & $\begin{array}{l}\text { Unknown } \\
\text { site, } \\
\text { possibly } \\
\text { near Grida } \\
\text { Avlaki }\end{array}$ & $\begin{array}{l}\text { Liko, Mavro Mouri } \\
4 c \text {, Rethymnon } \\
\text { fissure; Kharoumes } \\
2\end{array}$ & - & - & - & - \\
\hline $\begin{array}{l}\text { Candiacervus } \\
\text { sp. V; } \\
\text { Size group } 5\end{array}$ & $\begin{array}{l}\text { post- } \\
\text { cranial }\end{array}$ & $\begin{array}{l}\text { radius, } \\
\text { metacarpi, } \\
\text { metatarsi }\end{array}$ & $\begin{array}{l}\text { right radius, } \\
\text { MPUR 25, } \\
\text { holotype } \\
\text { (Capasso } \\
\text { Barbato 1992: } \\
\text { fig. 4) }\end{array}$ & Bate Cave & - & $\begin{array}{l}\text { Cervus } \\
\text { (Leptocervus) } \\
\text { dorothensis }\end{array}$ & $\begin{array}{l}\text { Pseudodama } \\
\text { (Leptocervus) } \\
\text { dorothensis }\end{array}$ & $\begin{array}{l}\text { ?Pseudodama } \\
\text { (Leptocervus) } \\
\text { dorothensis }\end{array}$ & $\begin{array}{l}\text { Candiacervus } \\
\text { dorothensis }\end{array}$ \\
\hline $\begin{array}{l}\text { Candiacervus } \\
\text { sp. VI; } \\
\text { Size group } 6\end{array}$ & $\begin{array}{l}\text { post- } \\
\text { cranial }\end{array}$ & metapodial & $\begin{array}{l}\text { metatarsus, } \\
\text { MPUR 30, } \\
\text { holotype } \\
\text { (Capasso } \\
\text { Barbato \& } \\
\text { Petronio 1986, } \\
\text { Tav. II.) }\end{array}$ & Bate Cave & Liko & $\begin{array}{l}\text { Cervus } \\
\text { (Leptocervus) } \\
\text { major }\end{array}$ & $\begin{array}{l}\text { Pseudodama } \\
\text { (Leptocervus) } \\
\text { major }\end{array}$ & $\begin{array}{l}\text { ?Pseudodama } \\
\text { (Leptocervus) } \\
\text { major }\end{array}$ & $\begin{array}{l}\text { Candiacervus } \\
\text { major }\end{array}$ \\
\hline
\end{tabular}

Barbato (1995) revised the latter three species to Pseudodama (Leptocervus) rethymnensis (Kuss, 1975), Pseudodama (L.) dorothensis (Capasso Barbato, 1990), and Pseudodama (L.) major (Capasso Barbato \& Petronio, 1986), respectively, without further clarifications. Moreover, Capasso Barbato (1995) revised Megaloceros (Candiacervus) ropalophorus to Megaceroides (Candiacervus) ropalophorus. Recently, van der Geer (2018) proposed to assign all six size groups of Cretan deer to the genus Candiacervus and specifically, to rename de Vos' Candiacervus sp. IIa, IIb, and IIc as Candiacervus listeri, C. devosi, and C. reumeri, respectively.
Thus, the assignment of the smaller species of Candiacervus to Megaceros Owen, 1844 / Megaloceros Brookes, 1828 / Megaceroides Joleaud, 1914 (Caloi \& Palombo 1996; Capasso Barbato 1989, 1990, 1995) indicates consideration of C. ropalophorus, C. listeri, C. devosi, C. reumeri, and C. cretensis (Simonelli, 1908) as dwarfed members of giant deer. In fact, this implies that these Candiacervus species belong to Megalocerotini Brookes, 1828 s.s., which comprises the genera Megaloceros, Megaceroides, and Dama, and which constitutes a phylogenetic branch (as outlined by Croitor 2016). This holds also for the views presented by 
other authors (e.g. Radulescu \& Samson 1967; Sondaar \& Boekschoten 1967; Caloi \& Palombo 1994). Van der Geer (2018) favored a close relationship of Candiacervus with the fallow deer, Dama, based on antler morphology. As Dama is more closely related to Megaloceros than to Cervus (Hughes et al. 2006; Immel et al. 2015; Mennecart et al. 2017) and has actually been considered to be the last living member of giant deer (Lister et al. 2005), this again supports a close relationship of Candiacervus with Megalocerotini s.s.

Vislobokova (2013) presented a reassessment of some of the cranial material described originally by de Vos (1984), compared it with material from giant deer, and also concluded that Candiacervus is a member of this group. However, it should be noted that her study comprises material of Megalocerotini s.l., which is considered a polyphyletic group of giant cervids (Croitor 2014, 2016).

The presumptive mainland relatives, or ancestors, of the medium-sized and larger morphotypes of Candiacervus, i.e., Candiacervus rethymnensis Kuss, 1975, Candiacervus dorothensis and Candiacervus major (Table 1) remain enigmatic, as do their relationships with the smaller species of Candiacervus. Whatever ancestor(s) gave rise to the Cretan deer, it has been criticized that none of the genera suggested "share synapomorphologies with Candiacervus that are not shared with other genera” (de Vos \& van der Geer 2002: 400).

Thus, despite the extensive studies cited above, the biological systematics of Cretan deer is still subject of debate (Table 1). Clearly, this discussion should profit from additional morphological data. Accordingly, in this study, we present undescribed, exquisitely preserved Candiacervus skull remains from Gerani, west of Rethymnon, Crete. We provide a detailed morphological and morphometric description, discuss it within the existing qualitative and quantitative framework and give a systematic assessment of the studied specimens. Our intentions are: 1) to complement previous character lists and species diagnoses; and 2) to highlight hitherto unknown traits and to interpret them in the context of island evolution and dwarfing in Cervidae.

\section{ABBREVIATIONS}

Institutional Abbreviations

AMPG Museum of Paleontology and Geology of the University of Athens, Athens;

MPUR Museo di Paleontologia, Università degli Studi di Roma 'La Sapienza', Rome;

NNML National Natuurhistorisch Museum, Leiden;

SNSB-BSPG Staatliche Naturwissenschaftliche Sammlungen Bayerns - Bayerische Staatssammlung für Paläontologie und Geologie, Munich.

\section{MATERIAL AND METHODS}

Eight skulls of Cretan deer or fragments thereof, stored at the SNSB-BSPG are described (SNSB-BSPG identification see Appendix 1). In the following text, we refer to specimens by their specific ID only, e.g. "SNSB-BSPG 1972 XIX 201" will be abbreviated to "1972 XIX 201', or simply by the last number of the ID, e.g. "201". The mate- rial comes from a cave near the village Gerani, to the west of Rethymnon; it was collected by H.-J. Gregor in 1971. The exact location of the cave remains unknown. However, according to H.-J. Gregor (pers. communication, September $28,2018)$, the cave entrance is at about five meters above sea level. The fossil site itself could be reached by crawling through a small tunnel and it extended approximately two meters in height and seven meters in length. Its sidewalls consisted of gravel and conglomerate, in which bones were embedded. H.-J. Gregor also noted that the material comes from the same cave he introduced to S. E. Kuss (Freiburg im Breisgau, Germany), in May 1971, and which the latter briefly mentioned in his paper of 1973 (Kuss 1973: 58). The description of the cave, however fragmentary, allows concluding that the material presented here does not come from one of the better-described sites (de Vos 1984; Lax 1991). Both H.-J. Gregor (pers. communication) and S. E. Kuss (1973) reported that they did not find bones of any other taxon than cervids at this location.

The precise geological age of our specimens is unclear. Kuss (1973) suggested that fossils from the respective layer were younger than the Grida-Avlaki-Fauna, which he previously correlated with the Riss/Würm Interglacial (Eem Interglacial, Tarantian, late Pleistocene) (Kuss 1970). Molars of Candiacervus ropalophorus from the nearby sites Gerani V and Gerani VI (Lax 1991) were dated by electron spin resonance dating to a corresponding age (Reese et al. 1996).

Specimens were covered with a layer of brownish calcareous sinter, typically formed in karst caves, as already noted by Kuss (1973), who visited the site in summer 1971. The sinter was removed mechanically in 2017 , just when we started the study.

Methodologically, we first undertook an extensive morphological comparison based on previous descriptions of Cretan deer (Simonelli 1908; Kuss 1975; Malatesta 1980; de Vos 1984) and described the studied material in detail. The relative biological age of our specimens was determined based on the wear patterns of the upper molars (van Bemmel 1949; de Vos 1984) and developmental stages of antlers.

Next, we obtained 37 skull and 4 dental variables that had been established in previous publications to describe Cretan deer (Simonelli 1908; Malatesta 1980; de Vos 1984; Vislobokova 2013) and allow us to integrate our findings with these seminal publications. These variables and their definitions are listed in Table 2. Linear measurements were taken with digital and mechanical calipers $(150 \mathrm{~mm}$ and $300 \mathrm{~mm}$, respectively). Angles were measured with a mechanical protractor/goniometer (resolution: $1^{\circ}$ ). Angles between lines to which the available goniometer could not be applied (because of its size) were measured in appropriately oriented and magnified photographs, using the "Measure"tool implemented in Gimp v.2.8.16 (http://www.gimp.org). Raw data are reported in Appendix 1. Relative sizes are given as percentages of the condylobasal length.

Basic descriptive statistics are reported in Table 3. For the coefficient of variation, values between 2 and 8 are indicative for individuals of a single population (Simpson et al. 1960; de Vos 1984). 
A

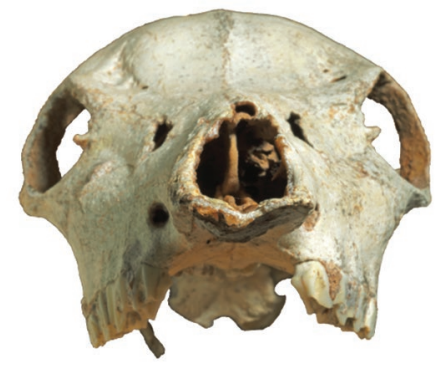

E

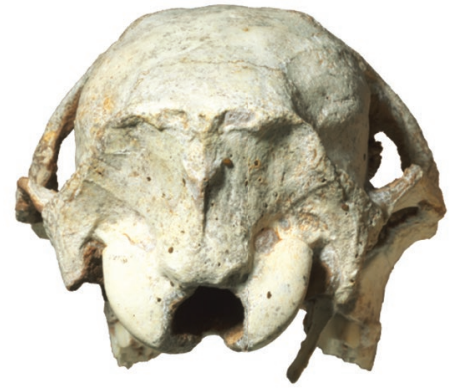

$\mathrm{F}$
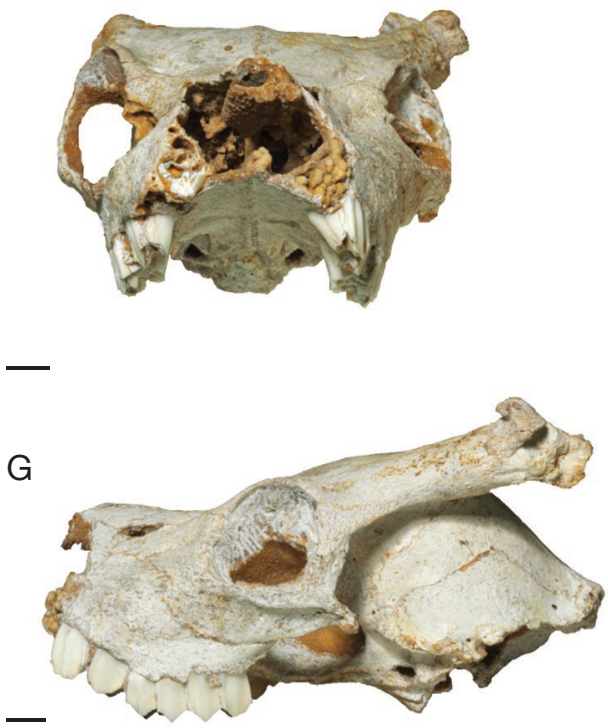

$\mathrm{H}$

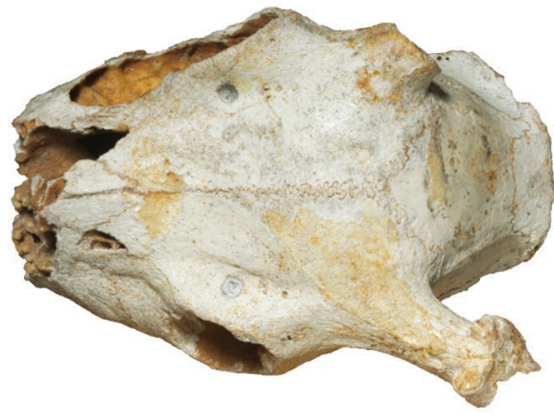

I

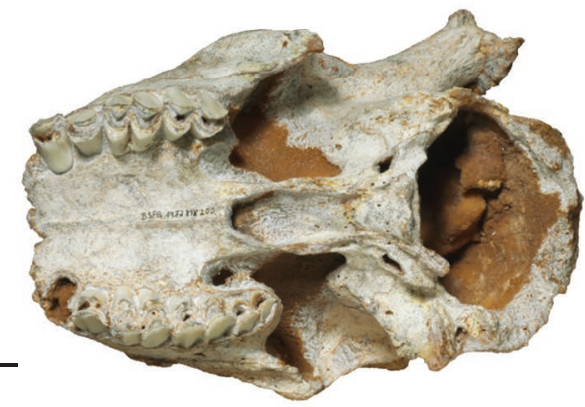

FIG. 1. - Candiacervus ropalophorus de Vos, 1984: A-E, SNSB-BSPG 1972 XIX 1; F-I, SNSB-BSPG 1972 XIX 200. The species typically has an interfrontal crest, visible in A and F; thick dorsal orbital rims, no contact between frontals and maxillae (B, G); and protocone and metaconule of similar size (D). SNSB-BSPG 1972 XIX 200 has weak rims on the left pedicle and bony pearls on a minimal burr (H). Its left M3 is in eruption (I). A, F, rostral view; B, G, left lateral view; C, H, dorsal view; D, I, ventral views; E, occipital view. A, B, E-G, dorsal to the top; B-D, G-I, rostral to the left. Scale bars: $1 \mathrm{~cm}$.

We compared the values of descriptive measures of teeth with those previously published and taken from specimens from Simonelli Cave and Gerani IV (Simonelli 1908; de Vos 1984; Appendix 1). In doing so, we exclude data of one specimen Simonelli (1908) reported on, as he could not reliably assign the isolated maxilla fragment with cheek teeth to any of his skull remains with sex-specific characters ("mascellare superiore appartenuto verosimilmente al teschio rappresentato dalle figures $1-4$ ", p. 9 [the upper jaw belonged probably to the skull represented by figures1-4]). We then compared the ranges of variation of our data with that of Simonelli (1908) and de Vos (1984).

We follow Croitor (2016) and refer to Megalocerotini s.l. as a polyphyletic group of giant forms of cervids, and Megalocerotini s.s. as comprising the genera Megaloceros, Megaceroides, and 
Dama (see also Introduction). In order to assess to which degree the adaptation to the insular environment has affected skull morphology of Cretan deer, we applied diagnostic, qualitative and quantitative traits defined by Vislobokova (2013) for Megalocerotini s.l.

\section{SYSTEMATIC PALEONTOLOGY}

Order ARTIODACTYLA Owen, 1848

Suborder RUMINANTIA Scopoli, 1777

Infraorder PECORA Flower, 1883

Family CERVIDAE Goldfuss, 1820

Subfamily Cervinae Goldfuss, 1820

Genus Candiacervus Kuss, 1975

TYPE SPECIES. - Anoglochis cretensis (Simonelli, 1908) from the late Pleistocene of Rethymnon Area (Crete, Greece), unknown site, possibly near Grida Avlaki (de Vos 1984) by subsequent designation of Kuss (1975).

\section{Candiacervus ropalophorus de Vos, 1984}

(Figs 1; 2; 3A-E)

Candiacervus ropalophorus de Vos 1984: 43. — van der Geer 2018: 5, fig. 3 .

Megaceros (Candiacervus) ropalophorus - Capasso Barbato 1990: 268, fig. 2; 1992: 192.

Megaceroides (Candiacervus) ropalophorus-Capasso Barbato 1995: 243, fig. 1. — Caloi \& Palombo 1996: 136, figs 10.5-10.7, 10.9-10.13.

Holotype. - Male skull Ge4-46 from the Late Pleistocene (van der Geer et al. 2006b); Gerani 4, 40 uppermost centimeters of cave filling (de Vos 1979, 1984).

REFERRED MATERIAL. - 1972 XIX 1, 1972 XIX 200, 1972 XIX 202, 1972 XIX 203, 1972 XIX 204.

\section{SPECIMENS}

\section{XIX 1 (Fig. 1A-E)}

The skull is complete, with the exception of the rostral part of the left frontal, and from a female, because pedicles and antlers are not developed. The basal M3s have fully erupted. The occlusal surfaces show medium wear. The paracone and metacone and the protocone and metaconule of M2 are separated by enamel ridges (van Bemmel 1949) This indicates that the animal is likely older than an early adult and younger than a middle-aged adult sensu de Vos (1984).

\section{XIX 200 (Fig. 1F-I)}

The specimen comes from a male because pedicles are present. On the left pedicle, there is a partial burr, i.e., a ring of bony pearls at the proximal end of the antler. The rest of the left antler is broken. The right pedicle is broken close to its base. The part of the occipital bone situated below the linea nuchae, the petrosals, and the snout are missing. Left P3 to M2 and right $\mathrm{P} 4$ to $\mathrm{M} 3$ are present. $\mathrm{P} 4, \mathrm{M} 1$, and $\mathrm{M} 2$ are little worn.
The $\mathrm{P} 3$ is unworn. In addition, the alveola of the right $\mathrm{P} 3$ are preserved. The paracone and protocone of $\mathrm{M} 2$ are not in contact with the dentine of the metacone and metaconule, respectively. The right M3 is only halfway erupted, indicating that we deal with an early adult. Caudal to the left foramen supraorbitale, a weakly developed bony rim can be identified and runs towards the lateral margin of the left pedicle. The axis of the pedicle and the midline of the frontal bone form an angle of $35^{\circ}$.

\section{XIX 202 (Fig. 2A-E)}

This is a female skull. There are neither pedicles nor antlers present. The left and right premaxilla, the left orbital rim, and both zygomatic arches are missing. The tooth rows are complete with P2 to M3 and M3s are fully erupted. Their occlusal surface is medium worn, but more heavily than in specimen 1 . The dentine of the paracone and metacone of M2 are in contact, while the dentine of protocone and metaconule are not yet in contact. Therefore, the individual was an older middle-aged adult at the time of its death.

\section{XIX 203 (Fig. 2F-J)}

The male skull has pedicles and, on the left one, the distal part may represent the proximal portion of a first generation, unbranched spike-like antler without burr (details on antler development see e.g. Davis et al. (2011)). The pedicle is slightly bent to lateral and bears the most proximal portion of a yearling antler without burr. The rest of the antler is broken and missing. The right pedicle is broken close to its base. Most of the rostral facial skull is missing, except for most caudal nasal and maxilla portions and the lacrimal bones. The left premolar row, the left M3 and the zygomatic arch are not preserved. The right $\mathrm{P} 2$ and $\mathrm{P} 3$ are also missing. The right M3 is in eruption. The teeth are little worn, hence the dentine of the paracone and protocone are not in contact with the dentine of the metacone and metaconule, respectively. The latter, the not fully erupted M3, and the presence of a first generation antler indicate that the specimen is from a relatively young or early adult. Bony rims at the base of the pedicles could not be discerned, contrary to what has been identified in specimen 200 (see above). The axis of the pedicle and midline of the frontal form an angle of $41^{\circ}$.

\section{XIX 204 (Fig. 3A-E)}

A female skull without pedicles and antlers. The premaxilla and right zygomatic arch are not preserved. The dentition is complete with left and right P2 to M3; the left P2 is slightly damaged. The occlusal surface is heavily worn; the right P2, both P3 and both M1 are worn down to the crown base, enamel islets almost disappeared. The dentition status indicates an old animal.

\section{DESCRIPTION}

Overall, these five skulls are gracile; they are widest at the caudal orbital border. Their facial part is longer than their cranial part, in particular; the snout is long and slender (Fig. 1B). The orbits are located at about the same distance from the snout 
TABLE 2. - Measurements, their abbreviations and definitions. Abbreviation: na, character ID not given in the reference.

\begin{tabular}{|c|c|c|c|c|}
\hline & Measurement, abbreviation & Landmarks or definition & Taken from & $\begin{array}{l}\text { Character ID } \\
\text { in reference }\end{array}$ \\
\hline 1 & Basilar length, BL & Prosthion-basion & de Vos (1984) & 1 \\
\hline 2 & Width bizygomatic, ZyZy & Zygion-zygion & de Vos (1984) & 2 \\
\hline 3 & Skull height, BLnsup & Linea nuchae superior-basion & de Vos (1984) & 3 \\
\hline 4 & Width of the occipital, OtOt & Otion-otion & de Vos (1984) & 4 \\
\hline 5 & Orbital width, DRC & Rostrocaudal diameter in the horizontal plane & de Vos (1984) & 5 \\
\hline 6 & Orbital height, DDV & Dorsoventral diameter in the vertical plane & de Vos (1984) & 6 \\
\hline 7 & Orbital shape & DVV/DRC & de Vos (1984) & Index 2 \\
\hline 8 & Relative orbit size & $\begin{array}{l}\text { (M2 length }+\mathrm{M} 3 \text { length, measured on the } \\
\text { occlusal surface) /DRC }\end{array}$ & Vislobokova (2013) & $\begin{array}{l}\text { General } \\
\quad \text { character, } 16\end{array}$ \\
\hline 9 & Skull flexion & $\begin{array}{l}\text { Angle between the forehead and the dorsal } \\
\text { surface of the braincase }\end{array}$ & Vislobokova (2013) & $\begin{array}{l}\text { General } \\
\text { character, } 1\end{array}$ \\
\hline 10 & $\begin{array}{l}\text { Inclination of the braincase roof relative to the } \\
\text { braincase axis }\end{array}$ & $\begin{array}{l}\text { Angle between dorsal surface of the braincase } \\
\text { and the horizontal basicranium }\end{array}$ & Vislobokova (2013) & $\begin{array}{l}\text { General } \\
\text { character, } 9\end{array}$ \\
\hline 11 & Greatest skull width & Width at the caudal orbital border & Vislobokova (2013) & $\begin{array}{l}\text { General } \\
\quad \text { character, } 12\end{array}$ \\
\hline 12 & $\begin{array}{l}\text { Inclination of the skull roof } \\
\text { and the occipital plane }\end{array}$ & $\begin{array}{l}\text { Angle between the upper and lower part of } \\
\text { the squama occipitalis (above and below the } \\
\text { linea nuchae superior) }\end{array}$ & Vislobokova (2013) & $\begin{array}{l}\text { General } \\
\text { character, } 4\end{array}$ \\
\hline 13 & $\begin{array}{l}\text { Greatest width of the supraorbital groove, } \\
\text { maxWSG }\end{array}$ & Maximal mediolateral extension of the groove & Vislobokova (2013) & $\begin{array}{l}\text { Generic } \\
\text { character, } 1.2\end{array}$ \\
\hline 14 & $\begin{array}{l}\text { Horizontal diameter of the supraorbital foramen, } \\
\text { DSF }\end{array}$ & Maximal mediolateral extension of the foramen & Vislobokova (2013) & $\begin{array}{l}\text { Generic } \\
\text { character, } 1.2\end{array}$ \\
\hline 15 & Proportion of supraorbital foramen to groove & maxWSG/ DSF & Vislobokova (2013) & $\begin{array}{l}\text { Generic } \\
\quad \text { character, } 1.2\end{array}$ \\
\hline 16 & Length of the foramen ovale & Rostrocaudal extension of the f. ovale & Vislobokova (2013) & $\begin{array}{l}\text { Generic } \\
\quad \text { character, } 6.4\end{array}$ \\
\hline 17 & Width of the foramen ovale & Mediolateral extension of the f. ovale & Vislobokova (2013) & $\begin{array}{l}\text { Generic } \\
\text { character, } 6.4\end{array}$ \\
\hline 18 & Shape of the foramen ovale & Length/Width of the $\mathrm{f}$. ovale & This study & \\
\hline 19 & Position of the foramen ovale & $\begin{array}{l}\text { Angle between the greatest axis of the f. ovale } \\
\text { and the sagittal skull plane }\end{array}$ & Vislobokova (2013) & $\begin{array}{l}\text { Generic } \\
\text { character, } 6.4\end{array}$ \\
\hline 20 & Length of the occipital & Lambda-Inion & Simonelli (1908) & na \\
\hline 21 & Length of the parietal & Lambda-Bregma & Simonelli (1908) & na \\
\hline 22 & Length of the frontal & Bregma-Nasion & Simonelli (1908) & na \\
\hline 23 & $\begin{array}{l}\text { External distance between foramina } \\
\text { supraorbitalia }\end{array}$ & $\begin{array}{l}\text { Maximal diameter between the foramina } \\
\text { supraorbitalia }\end{array}$ & Simonelli (1908) & na \\
\hline 24 & $\begin{array}{l}\text { Inclination of the tympanic bullae relative to the } \\
\text { meatus acusticus }\end{array}$ & $\begin{array}{l}\text { Angle between the major axis of the tympanic } \\
\text { bullae and the transversal axis of the external } \\
\text { meatus acusticus }\end{array}$ & Vislobokova (2013) & $\begin{array}{l}\text { Generic } \\
\text { character, } 7.2\end{array}$ \\
\hline 25 & Position of the external meatus acusticus & $\begin{array}{l}\text { Angle between the transversal axis of the } \\
\text { external meatus acusticus and the median } \\
\text { plane }\end{array}$ & Vislobokova (2013) & $\begin{array}{l}\text { Generic } \\
\text { character, } 7.2\end{array}$ \\
\hline 26 & Orientation of the orbit & $\begin{array}{l}\text { Angle between the left and right } \\
\text { anteroposterior orbital diameter in a } \\
\text { horizontal plane }\end{array}$ & Vislobokova (2013) & na \\
\hline 27 & Klinorhynchy & $\begin{array}{l}\text { Angle between the horizontal basicranium and } \\
\text { the palatine plane }\end{array}$ & Starck (1979) & \\
\hline 28 & Frontal breadth 1 & Frontal breadth at the constriction in males & Croitor (2018) & 18 \\
\hline 29 & Frontal breadth 2 & Frontal breadth behind the pedicles in males & Croitor (2018) & 19 \\
\hline 30 & Facial length & Anterior edge of orbit to prosthion & Croitor (2018) & 11 \\
\hline 31 & Condylobasal length, CBL & $\begin{array}{l}\text { Posterior edges of the occipital condyles to } \\
\text { prosthion }\end{array}$ & Croitor (2018) & 1 \\
\hline 32 & Relative facial length & Facial length/CBL & & \\
\hline 33 & Muzzle length & P2 to prosthion & Croitor (2018) & 5 \\
\hline 34 & Relative muzzle length & Muzzle length/ CBL & & \\
\hline 35 & Length of the braincase & Bregma to opisthion & Croitor (2018) & 7 \\
\hline 36 & Greatest width of braincase & Euryon-Euryon & & \\
\hline 37 & Relative length of braincase & $\begin{array}{l}\text { Length of braincase/greatest width of } \\
\text { braincase }\end{array}$ & & \\
\hline 38 & Length of the premolar row, $\mathrm{P} 2 \mathrm{P} 4$ & $\begin{array}{l}\text { Distance between P2 and P4 taken at the level } \\
\text { of the gum }\end{array}$ & Simonelli (1908) & na \\
\hline 39 & Length of the molar row, M1M3 & $\begin{array}{l}\text { Distance between M1 and M3 taken at the } \\
\text { level of the gum pad }\end{array}$ & Simonelli (1908) & na \\
\hline 40 & Relationship between molar and premolar row & M1M3/P2P4 & This study & \\
\hline 41 & Length of tooth row, P2M3 & $\begin{array}{l}\text { Distance between the P2 and M3 taken at the } \\
\text { level of the gum pad }\end{array}$ & Simonelli (1908) & na \\
\hline
\end{tabular}


tip and the occiput (Fig. 1B). The skulls are klinorhynchic (Starck 1979), i.e., the palatine plane is inclined downwards in relation to the horizontal basicranium. The angle encompassed by the two bones is about $170^{\circ}$ (Table 3 ).

\section{THE FACIAL SKULL}

From a lateral and rostral view, the facial skeleton shows a clear flexion of the frontal between the orbits. The interfrontal suture is slightly prominent in both males and females (Figs 1A, B, F, G; 2F, G; 3A, B). Since the prominence is equally developed in both the early $(200,203)$ and the old (204) adults, it does not seem to be an age-dependent trait. Malatesta identified the same "crest" (1980, p. 21) in male specimens of Candiacervus reumeri (van der Geer, 2018) from Simonelli cave. While this crest continues caudally in females up to the point where antlers develop in males, such eminence is not discernible in the two males (Figs 1F; 2F). The supraorbital grooves are weakly developed in all specimens. The foramen supraorbitale is large (c. $50 \%$ of the width of the supraorbital groove, Appendix 1) and circular. The two foramina lie at a greater transversal distance than the ethmoidal gaps, such that straight lines connecting the foramina and ethmoidal gaps transversally and rostrocaudally form a trapezium.

The orbits are roundish, quantified by the ratios of the dorsoventral and rostrocaudal diameters equaling one (Appendix 1). The orbits are small, with the rostrocaudal orbital diameter as long as the length of M2 + M3 (Appendix 1). The caudal orbital rims (= postorbital bar) are triangular in cross-section and robust; with the robust zygomatic arch, they form an angle of approximately $90^{\circ}$. The dorsal orbital rim is roundish and thick, rising slightly above the frontal bones (Figs 1A, F; 2A; 3A) and conforms to the description by de Vos (1984). The rostral orbital border is above M2 (Figs 1G; $2 \mathrm{G}$ ) or above the border between M2 and M3 (Figs 1B; 2B; 3B).

Rostrally to the orbit extends the lacrimal bone. Its facial facet makes up part of the orbital rim, contacts the jugal and the maxilla ventrally and the frontal bone dorsally, as in living cervid species. It forms a pentagon, narrow in the dorsoventral direction and elongated in the rostral-caudal direction. The angle between the lacrimojugal and the lacrimomaxillar sutures is approximately $180^{\circ}$. Two lacrimal orifices, as typical for cervids (Leinders \& Heintz 1980), can be recognized in all specimens. One is located on the orbital rim, the other one is located slightly more rostrally. In specimens 1 and 203, a little protuberance is preserved and separates these two orifices (Figs 1A; 2F). There is no preorbital depression in the lacrimal facial facet. A relatively small, clear, and triangular ethmoidal gap can be recognized in all specimens.

The nasals are cruciform, having their widest lateral extension at the level of the ethmoidal gap. Caudally, the nasal bones converge to an apex. The latter and the nasofrontal suture are located rostrally to the level of the rostral orbital border (Figs 1C, H; 2C, H; 3C). From the rostral view, the shape of the nasal cavity is arched, narrow and high. The nasal septum does not completely divide the nasal cavity in a dorsoventral direction (Figs 1A; 3A).
The maxilla presents a bulge instead of a facial crest and the maxillary tubercle is discernible. A small tuber above M1 can be identified. The premaxillae are slightly widened caudally; the outline of its most rostral part is rectangular (Fig. 1C, D). Ventrally, the sinistral and dextral margo interalveolaris between P2 and the praemaxillo-maxillar suture run in parallel to each other.

The maxillopalatine suture has a rectangular outline. The rostrocaudal portion of the suture runs in parallel to the molars; the other one runs straight in a transversal direction (see e.g. Fig. 1D). The ventral position of the transversal part is quite variable. In specimens 1 and 200, this suture meets M1 right between the protocone and the metaconule. In specimen 202, the suture is at the height of the anterior border of M2. In specimen 204, this suture meets M2 right between the protocone and the metaconule. The foramina palatinae are located either in the corners, where the rostrocaudal and transversal parts of the maxillopalatine suture meet, or slightly shifted rostrally or caudally to the transversal part of this suture.

The spina nasalis caudalis of the palate, if present at all, is very weakly developed (Figs 1D; 2D; 3D). The location of the pterygopalatine fossae relative to the molars is variable: they are located at the level of the caudal border of M3 (Figs 1D; 2J; 3D) or half of M2 (Figs 1I; 3D). If present at all, a ventral projection on the pterygoid (hamulus pterygoideus) is only partially preserved (Fig. 1D).

\section{THE NEUROCRANIUM}

The braincase is, on average, as long as wide (Table 3). In dorsal view, the shape of the braincase is oval, i.e., it does not expand caudally (Figs 1C, H; 2C, H; 3C). The temporal lines converge from the linea nuchae superior towards the lambdoid suture and then diverge to the base of the pedicles in one of the males (Fig. $1 \mathrm{H}$ ) and until the base of the zygomatic process in females (Figs 1C; 3C). In specimens 202 and 203, the lines are less developed. An interparietal prominence can be tactually, but hardly visually recognized. Fossae located laterally to the interparietal eminence are absent, with the possible exception of weakly developed ones in specimen 204. A parietal foramen cannot be discerned. The frontoparietal suture is straight. Specimen 204 has a slight depression at the junction of the dorsal midline and the frontoparietal suture (Fig. 3C). The linea nuchae superior is well developed and slightly arched, in both males and females. The latter is even more pronounced in the older specimens of our sample. The upper and lower portions of the squama occipitalis comprise either a right or an obtuse angle when seen from lateral (Appendix 1) and the occipital condyles do not protrude beyond the caudal border of the occiput (Figs 1B; 2B, G; 3B). Due to its size, the foramen ovale can be easily identified at the basisphenoid.

In all four specimens in which the occiput is preserved (Figs 1E; 2E, J; 3E), it consists of a single bone with a weakly developed protuberantia occipitalis externa. The latter occupies approximately half of the dorsoventral height of the occiput (Fig. 1E). While the shape of the protuberantia cannot be assessed in the male specimen (Fig. 2J), it is rhomboid in the remaining three, female specimens. The median occipital crest, 
A

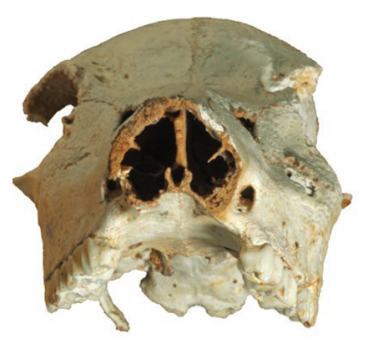

$\mathrm{E}$

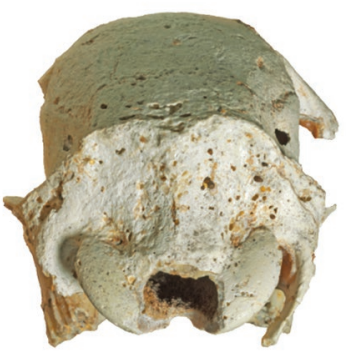

B
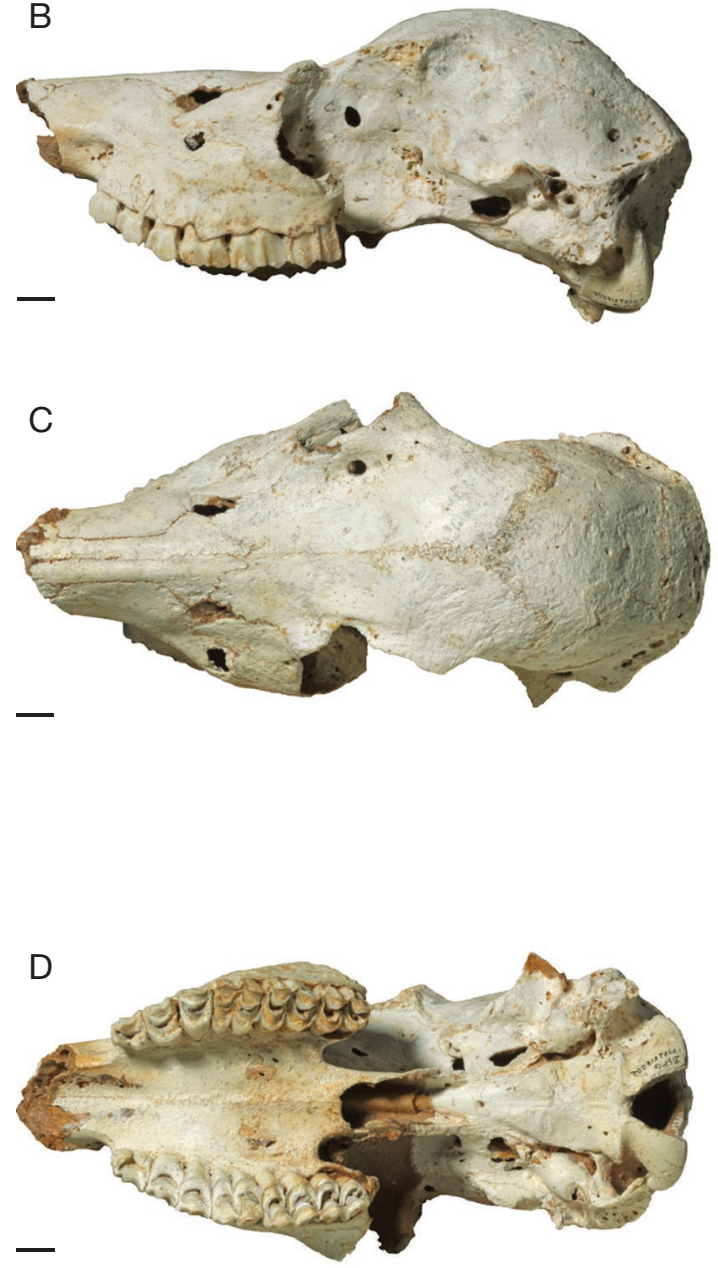

$\mathrm{F}$
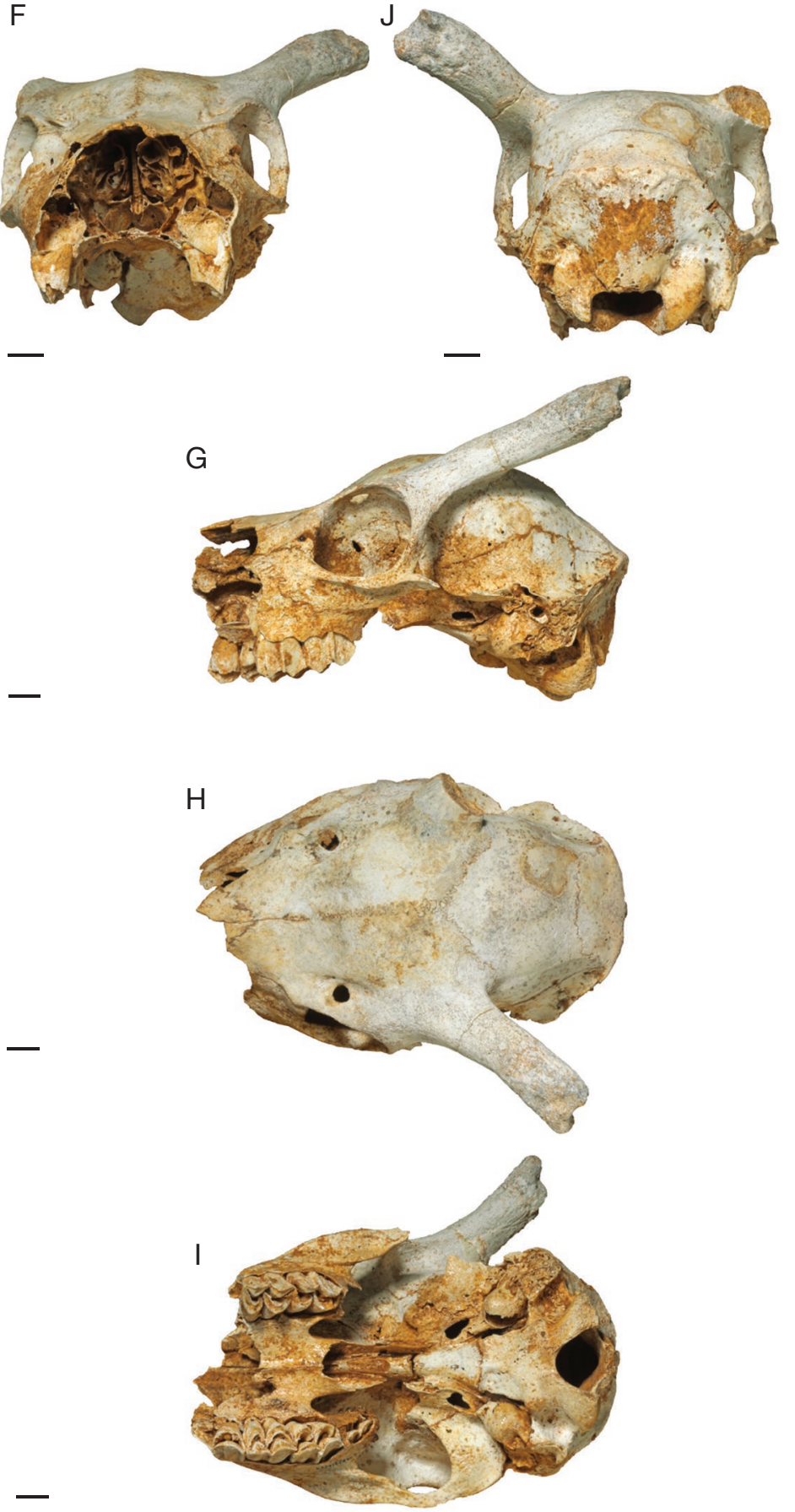

FIG. 2. - Candiacervus ropalophorus de Vos, 1984: A-E, SNSB-BSPG 1972 XIX 202; F-J, SNSB-BSPG 1972 XIX 203. Right M3 is in eruption (I). A, F, rostral view; B, G, left lateral view; C, H, dorsal view; D, I, ventral view; E, J, caudal view. A, B, E-G, J, dorsal to the top; B-D, G-I, rostral to the left. Scale bars: $1 \mathrm{~cm}$.

despite being sharp-edged, is still quite delicate (Figs 1E; 2E, J; 3E). At the dorsocaudal end of the occiput, the nuchal fossae on either side of this crest are wide and arched. Laterally, the petrosal part of the temporal bone flanks the occiput, extending to about the middle of the occipital height. The processus paracondylaris descends in parallel to the lateral edge of the condyles and extend a bit more ventrally (Figs 1E; 2E).

The braincase roof is generally in an acute angle to the braincase axis (Appendix 1). The external auditory canal is round with a longitudinal groove (Figs $1 \mathrm{~B} ; 2 \mathrm{~B}, \mathrm{G} ; 3 \mathrm{~B})$. From a ventral view, the tympanic bullae are inflated; in specimen 1 and 204, they are less inflated than in other specimens (Figs 1D; $3 \mathrm{D} v$ s. Fig. 2D, I). The bullae present a long rostral process (Fig. 2I) and their ventral surfaces do not descend below the ventral surface of the basioccipital. The pyramidal petrosal part of the temporal bone is pressed to the basioccipital. It separates the lacerate foramen from the jugular foramen. The basioccipital is wide, narrowing rostrally, with sharp, lateral 
TABLE 3. - Summary statistics for 36 craniodental variables for all the specimens described here. If the values of the coefficient of variation are between 2 and 8 , then individuals are from a single population (de Vos 1984; Simpson et al. 1960). Variables for which only one specimen is available have been omitted. Lengths in $\mathrm{mm}$, angles in degree. Abbreviations: Sd, Standard deviation; CV, coefficient of variation, given in percent; $\mathbf{C V}^{*}$, coefficient of variation, for which specimen -201 has been excluded, given in percent; Min, minimum; Max, Maximum.

\begin{tabular}{|c|c|c|c|c|c|c|c|c|}
\hline & $\mathbf{n}$ & Mean & Sd & Median & CV & $\mathrm{CV}^{*}$ & Min & Max \\
\hline 2. Width bizygomatic & 2 & 92.31 & 7.76 & 92.31 & 8.40 & 8.40 & 86.82 & 97.79 \\
\hline 3. Skull height & 4 & 48.48 & 1.08 & 48.50 & 2.23 & 2.23 & 47.15 & 49.76 \\
\hline 4. Width of the occipital & 4 & 68.54 & 5.20 & 70.29 & 7.58 & 7.58 & 61.00 & 72.60 \\
\hline 5. Orbital width & 7 & 29.38 & 0.94 & 29.38 & 3.19 & 3.49 & 28.00 & 30.93 \\
\hline 6. Orbital height & 7 & 28.52 & 1.53 & 28.16 & 5.38 & 5.70 & 26.56 & 31.23 \\
\hline 7. Orbital shape & 7 & 0.97 & 0.06 & 0.95 & 5.79 & 6.18 & 0.90 & 1.04 \\
\hline 8. Relative orbit size & 7 & 0.90 & 0.08 & 0.92 & 8.89 & 3.15 & 0.79 & 0.97 \\
\hline 9. Skull flexion & 5 & 103.70 & 5.72 & 101.50 & 5.52 & 5.52 & 99.80 & 112.00 \\
\hline $\begin{array}{l}\text { 10. Inclination of the braincase roof relative to the } \\
\text { braincase axis }\end{array}$ & 4 & 16.55 & 1.13 & 16.08 & 6.84 & 6.84 & 15.44 & 18.09 \\
\hline 11. Greatest skull width & 6 & 111.49 & 1.76 & 111.47 & 1.58 & 1.58 & 109.83 & 114.00 \\
\hline 12. Inclination of the skull roof and the occipital plane & 4 & 93.05 & 4.32 & 94.45 & 4.64 & 4.64 & 87.00 & 96.30 \\
\hline 13. Greatest width of the supraorbital groove & 6 & 9.81 & 1.08 & 9.88 & 11.00 & 9.84 & 8.55 & 11.38 \\
\hline 14. Horizontal diameter of the supraorbital foramen & 6 & 5.14 & 0.48 & 5.12 & 9.26 & 9.26 & 4.46 & 5.79 \\
\hline 15. Proportion of supraorbital foramen to groove & 6 & 0.53 & 0.05 & 0.53 & 9.47 & 8.27 & 0.45 & 0.59 \\
\hline 16. Length of the foramen ovale & 5 & 8.76 & 2.18 & 8.58 & 24.91 & 24.91 & 6.48 & 11.10 \\
\hline 17. Width of the foramen ovale & 5 & 5.28 & 1.24 & 5.02 & 23.37 & 23.37 & 4.12 & 6.84 \\
\hline 18. Shape of the foramen ovale & 5 & 1.67 & 0.27 & 1.62 & 16.19 & 16.19 & 1.35 & 2.08 \\
\hline 19. Position of the foramen ovale & 5 & 33.72 & 2.42 & 34.50 & 7.19 & 7.19 & 29.85 & 35.80 \\
\hline 20. Length of the occipital & 5 & 18.31 & 1.71 & 18.25 & 9.36 & 9.36 & 16.44 & 20.32 \\
\hline 21. Length of the parietal & 5 & 45.88 & 2.48 & 45.60 & 5.41 & 5.41 & 42.67 & 49.31 \\
\hline 22. Length of the frontal & 5 & 61.57 & 3.83 & 61.63 & 6.22 & 6.22 & 57.04 & 66.36 \\
\hline 23. External distance between foramina supraorbitalia & 5 & 52.26 & 4.49 & 53.20 & 8.60 & 9.43 & 45.79 & 57.34 \\
\hline $\begin{array}{l}\text { 24. Inclination of the tympanic bullae relative to the } \\
\text { meatus acusticus }\end{array}$ & 4 & 128.47 & 2.78 & 128.40 & 2.16 & 2.16 & 125.91 & 131.19 \\
\hline 25. Position of the external meatus acusticus & 4 & 92.98 & 2.44 & 94.13 & 2.63 & 2.63 & 89.32 & 94.36 \\
\hline 26. Orientation of the orbit & 6 & 59.98 & 2.78 & 59.20 & 4.63 & 4.66 & 57.61 & 65.45 \\
\hline 27. Klinorhynchy & 3 & 169.65 & 2.09 & 169.63 & 1.23 & 1.23 & 167.58 & 171.75 \\
\hline 28. Frontal breadth 1 & 2 & 55.72 & 2.33 & 55.72 & 4.16 & 4.16 & 54.07 & 57.36 \\
\hline 29. Frontal breadth 2 & 2 & 80.39 & 1.49 & 80.39 & 1.85 & 1.85 & 79.33 & 81.44 \\
\hline 35. Length of the braincase & 5 & 62.82 & 1.7 & 62.37 & 2.71 & 2.71 & 61.03 & 65.01 \\
\hline 36. Greatest width of braincase & 5 & 62.78 & 1.35 & 62.6 & 2.15 & 2.15 & 61.3 & 65 \\
\hline 37. Relative length of braincase & 5 & 100.09 & 3.44 & 98.58 & 3.44 & 3.44 & 97.49 & 106.05 \\
\hline 38. Length of the premolar row & 5 & 28.02 & 1.23 & 28.05 & 4.38 & 4.94 & 26.20 & 29.29 \\
\hline 39. Length of the molar row & 7 & 38.85 & 3.25 & 40.41 & 8.36 & 6.46 & 33.75 & 42.11 \\
\hline 40. Relationship between molar and premolar row & 5 & 0.75 & 0.07 & 0.75 & 9.18 & 9.06 & 0.65 & 0.82 \\
\hline 41. Length of tooth row & 5 & 64.04 & 3.65 & 63.75 & 5.70 & 6.45 & 58.68 & 67.73 \\
\hline
\end{tabular}

edges. Its surface is slightly concave or flat, with a median crest and large fossae caudal to muscular tubercles. Muscular tubercles are weakly developed in females and in one of our male specimens (203). They cannot be assessed in the other male specimen (200), as there is no basioccipital preserved. The foramen ovale of the sphenoid is large and ovate, no vascular foramen rostral to the foramen ovale could be discerned in any of our specimens.

\section{DENTITION}

Specimen 1972 XIX 1 is characterized by a complete and well-preserved upper dentition. Hence, it offers itself as a reference for $C$. ropalophorus (Fig. 1D). We could not identify any trace of upper canines or their alveolae (Fig. 1D). M3 is the last tooth to erupt, even after premolars have erupted (see early adult males; Figs 1I; 2I). Whereas the molar row runs essentially in parallel to the midline of the skull, the premolars form a slightly curved row that rostrally gets closer to the midline. (Figs 1D; 2D; 3D). The premolar row is shorter than the molar row (Appendix 1). For specimen 1, M3 is slightly smaller than M2 (Fig. 1D).

In P2, the protocone and metaconule are of the same size and thus, this premolar can be classified as morphotype 1 according to de Vos (1984). In P3 and P4, the lingual wall consists of the protocone only. In the P3, the two cusps are equally developed, while in the P4, the protocone is better developed than the metaconule. Specimen 202 presents a cingulum on the left P3 (Fig. 2D).

In M1 and M2, the posterior lobe is of the same length and width as the anterior lobe; in M3, the posterior lobe is narrower and shorter than the anterior one, as typical for Megalocerotini s.l. (Vislobokova 2013). Styles on the upper molars are of the same width at the base and in the apical half of the crown.

Individual dental wear of the upper premolars and molars allows for the following ordering of the specimens according to their ontogenetic stage, from younger to older: $203<200$ $<1<202<5<201<204$. 

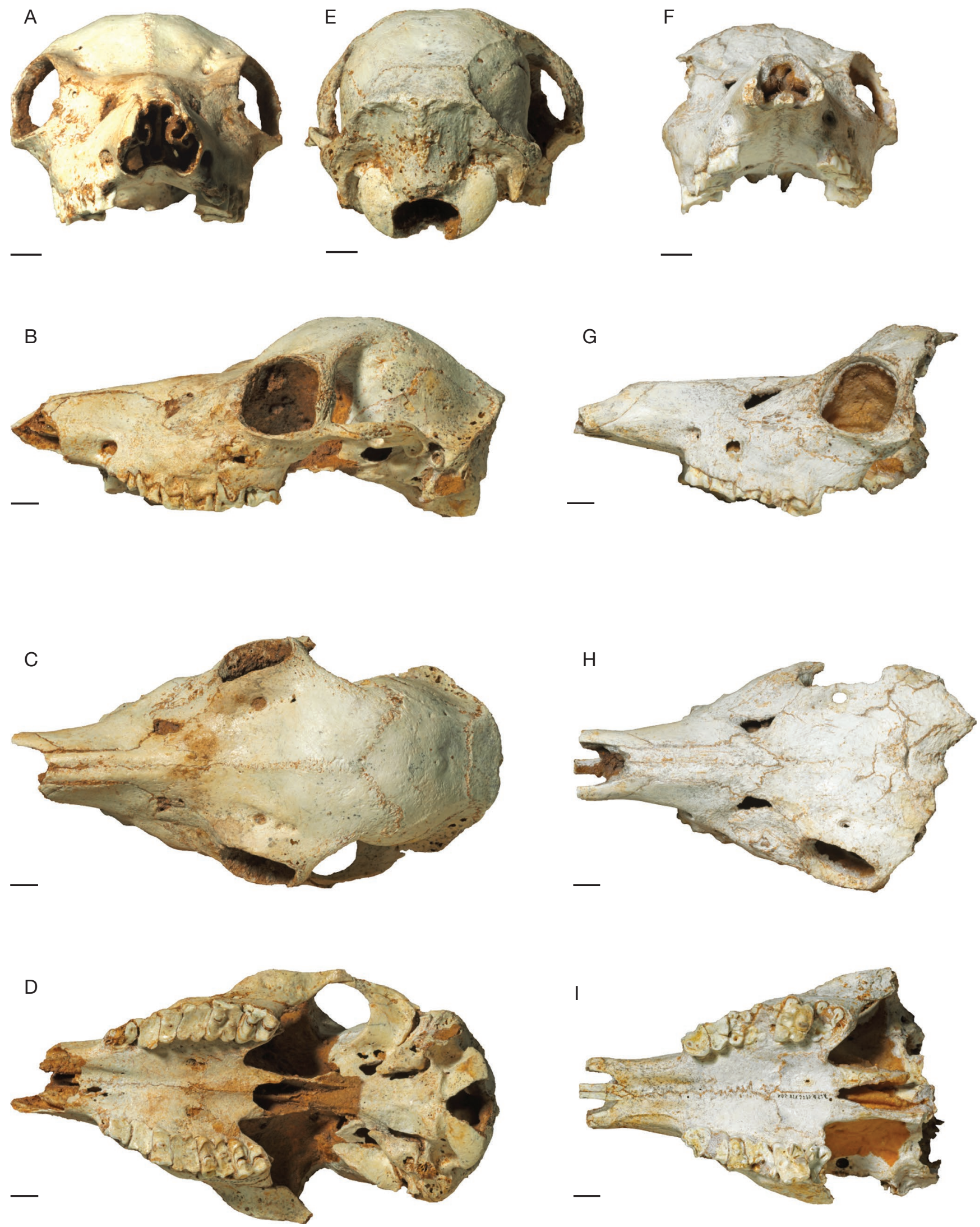

FIG. 3. - A-E, Candiacervus ropalophorus de Vos, 1984, SNSB-BSPG 1972 XIX 204; F-J, Candiacervus reumeri van der Geer, 2018, SNSB-BSPG 1972 XIX 201. C. reumeri lacks an interfrontal crest $(F)$, has thin dorsal orbital rims $(H)$, and the protocone is smaller than the metaconule (I). Also note the differently sized foramina supraorbitalia and the strong sinus of the frontal bones caudally $(H)$. The frontals touch the maxilla above the ethmoidal gap (G, H). A, F, rostral view; B, G, left lateral view; C, H, dorsal view; D, I, ventral view; E, caudal view. A, B, E-G, dorsal to the top; B-D, G-I, rostral to the left. Scale bars: $1 \mathrm{~cm}$. 


\author{
Candiacervus reumeri \\ van der Geer, 2018 \\ (Fig. 3F-I)
}

Candiacervus reumeri van der Geer, 2018: 12.

Candiacervus sp. IIc - de Vos 1984: 44, pl. 14. — Dermitzakis \& de Vos 1987: 393, fig. 10d.

Megaceros (Candiacervus) ropalophorus - Capasso Barbato 1990: 268, fig. 2; 1992: 192; 1995: 243.

Candiacervus sp. IIc - de Vos 1996: 113; 2000: 127. — van der Geer et al. 2006: 120; 2010: 54, 58.

HoLOTYPE. - Male skull AMPG(V) 1736 from the Late Pleistocene; Liko Cave, 75 uppermost $\mathrm{cm}$ of the cave filling (Likotinara, Crete, Greece) (van der Geer 2018).

REFERRED MATERIAL. — 1972 XIX 201.

\section{SPECIMEN}

\section{XIX 201}

The skull belongs to a specimen of unknown sex, possibly male, as the right part of the skull seems to continue into a pedicle. The neurocranium and the premaxillae are missing. Both tooth rows are complete with P2 to M3, with M3 broken on the right side. The occlusal surfaces are heavily worn, both M1s and M3s and the left P4 are worn down to the gum pad. Enamel islets have disappeared, except for P2s. This indicates the specimen stems from a rather old animal.

\section{DESCRIPTION}

This species is very similar to Candiacervus ropalophorus. In particular, from a ventral view, canine alveolae in the maxilla are absent. The transversal part of the maxillopalatine suture is at the height of the anterior border of M2. The spina nasalis caudalis of the palate is very weakly developed. The pterygopalatine fossae are located at the level of the caudal border of M3 (Fig. 3I).

C. reumeri differs from C. ropalophorus in having a thinner dorsal orbital rim (Fig. $3 \mathrm{H}$ ) and its rostral orbital border is above M2 (Fig. 3G). The orbits appear to be smaller than in C. ropalophorus because the length of $\mathrm{M} 2+\mathrm{M} 3$ is shorter in C. reumeri.

At the caudal portion of the interfrontal suture, the frontal bones present a strong sinus and at the rostral portion, the skull lacks the crest which is typical in the above described $C$. ropalophorus specimens. The supraorbital foramina are of different size, with the right one being the larger (Fig. 3H). The supraorbital grooves are deeper than in $C$. ropalophorus with sharp edges and the nasofrontal contact is shorter than in specimen 1. Moreover, contrary to $C$. ropalophorus, the frontal bones touch the maxilla above the ethmoidal gap; consequently, the nasals do not form part of the ethmoidal gap rim. The metaconule of the right P2 is larger than the protocone. For the left P2, these two cones are not well separated.

\section{Candiacervus sp.}

(Fig. 4)

REFERRED MATERIAL. — 1972 XIX 5, 1972 XIX 7.

\section{SPECIMENS}

\section{XIX 5 (Fig. 4A-D)}

The specimen comprises two fragments of the facial skull. One fragment consists of a small part of the maxilla with the still attached left tooth row (P2 to M3) (Fig. 4A, C). The other fragment comprises the right tooth row (P2 to M3), part of the palate, the lacrimal bone and the rostral part of the right orbit (Fig. 4B, D). The lacrimal bone is damaged. The sex is unknown. The occlusal surfaces of teeth are heavily worn; the dentine of the paracone and metacone of M2 are in contact and so is the dentine of protocone and metaconule. The latter indicates an old animal, elder than specimen 1, but younger than specimen 201. The premolars and M1 are more heavily worn than M2 and M3.

\section{XIX 7 (Fig. 4E, F)}

The fragment comprises the left facial skull, i.e., part of the maxilla, the lacrimal bone, the orbita, the jugal and part of the frontal bone. The skull fragment comes from a male, as left pedicle and a short, spike-like antler with a burr are present. The tooth row is completely missing. Age determination on dental wear is not possible. However, cranial sutures are hardly recognizable, the pedicle has a larger diameter than that of the other two males in our sample and the left antler is degenerated. Taken together, this indicates that we deal with a rather old individual.

\section{DESCRIPTION}

Overall, given the fragmentary status of the two specimens, little can be added to what has been already described for C. ropalophorus. The dorsal orbital rim is roundish and thick (Fig. 4E) and conforms to the description by de Vos (1984). The rostral orbital border is above M2 (Fig. 4B, E). In contrast to $C$. ropalophorus, the gracile zygomatic arch and caudal orbital rim form an acute angle (Fig. 4E). The transversal part of the maxillopalatine suture meets $\mathrm{M} 2$ right between the protocone and the metaconule (Fig. 4C, D). The dental characters (Fig. 4C, D) do not differ from those described for $C$. ropalophorus. There are a protocone and metaconule on both P3 and P4. Both the right and the left P4 have a cingulum, well developed in the former and less developed in the latter tooth. The M3s of this specimen are slightly smaller than M2s. An entostyle is present on M2s and M3s. M1s are too worn to be specific on that area.

\section{QUANTITATIVE ANALYSES}

Basic summary statistics (Table 3 ) indicate that the variability of most measures obtained is low to moderate, as documented by their rather narrow range, and also by their coefficient of variation. Exceptions to this are the length and width of 
A

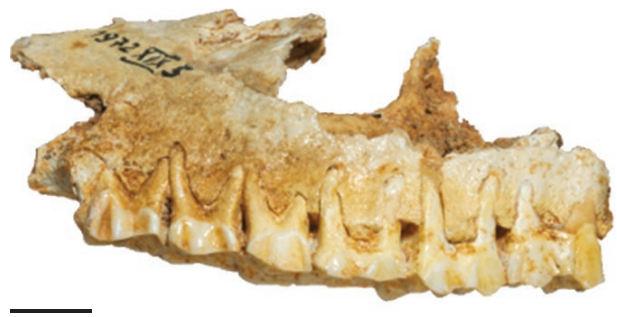

B

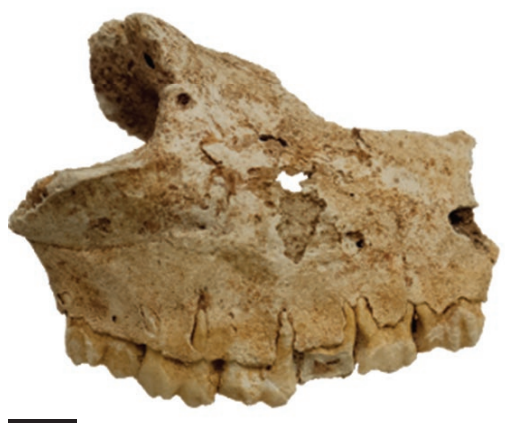

C

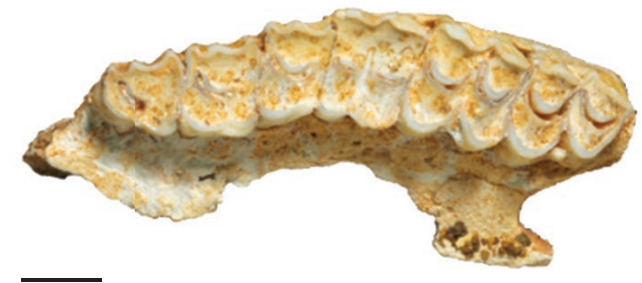

D
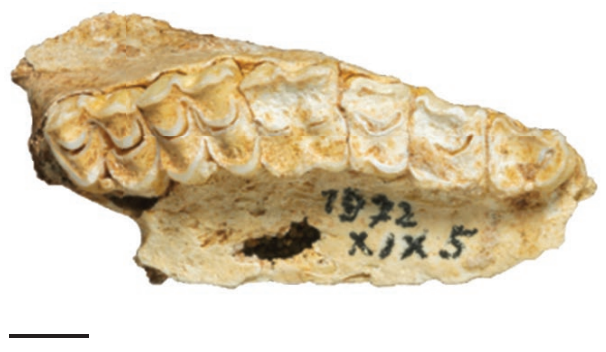
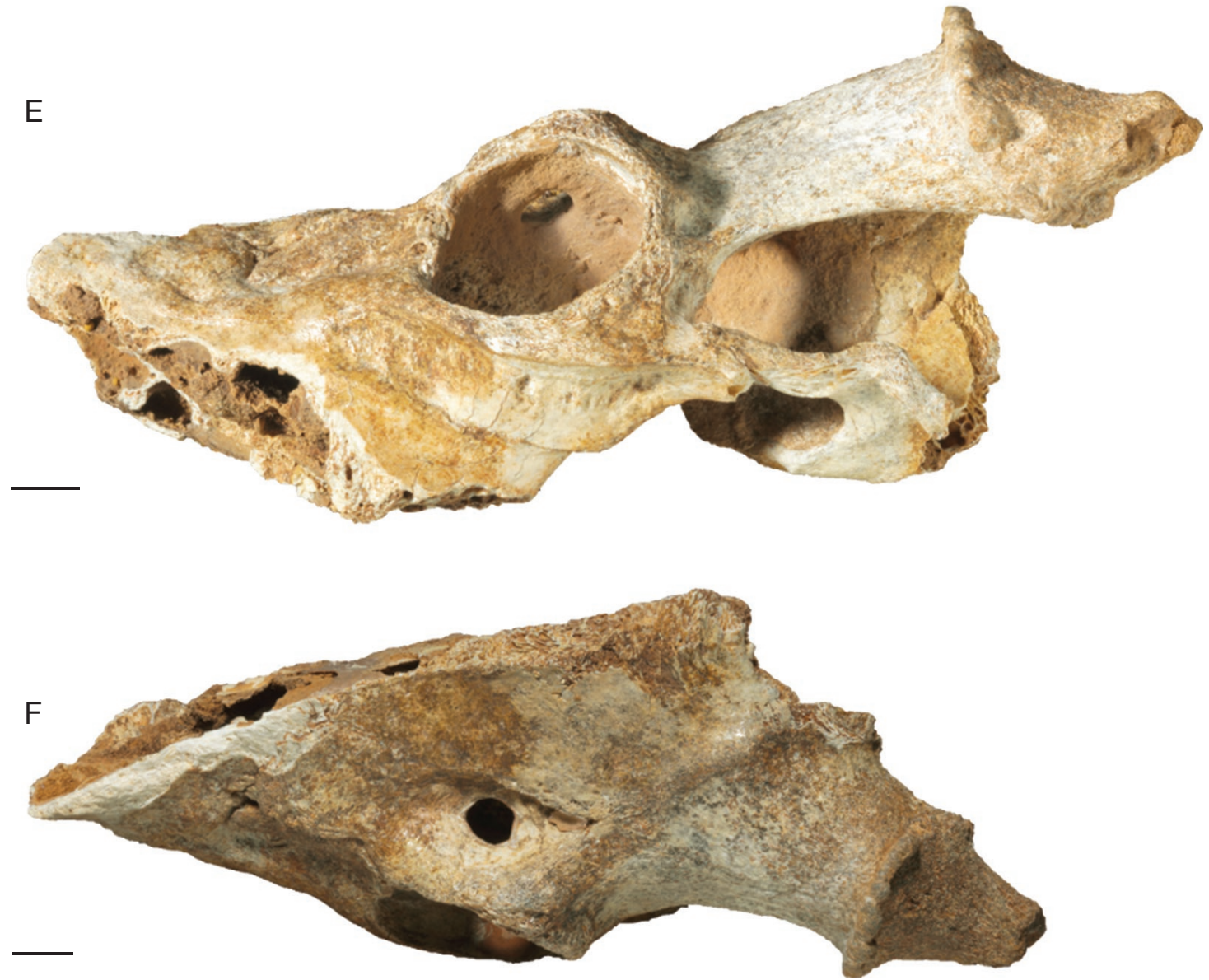

FIG. 4. - Candiacervus sp.; A-D, SNSB-BSPG 1972 XIX 5; E-F, SNSB-BSPG 1972 XIX 7. A, C, E, fragment of the left facial skull; rostral to the left; B, D, fragment of the right facial skull with cheek tooth row; rostral to the right; A, B, E, lateral views; C, D, occlusal views; F, dorsal view. Scale bars: $1 \mathrm{~cm}$. 
TABLE 4. - Application of binary characters for Megalocerotini Brooke, 1828 s.l. (= Megacerini, Viret 1961) and s.s. (= Dama, Megaloceros and Megaceroides), according to Croitor (2016), to the dwarf Candiacervus. Data for Megalocerotini are taken from Vislobokova (2013). Mean data from Table 3 are reported to facilitate comparison.

\begin{tabular}{|c|c|c|c|}
\hline \multicolumn{3}{|c|}{ Vislobokova 2013} & \multirow{2}{*}{$\begin{array}{l}\text { Results for Candiacervus } \\
\text { in this study }\end{array}$} \\
\hline Character ID & Character & Description or values & \\
\hline 1 & Skull bend & $\begin{array}{l}>130^{\circ} \text {...Megacerini; } \\
120^{\circ} \text {...Candiacervus listeri; Cervus elaphus } \\
110^{\circ} \ldots \text {..Dama dama }\end{array}$ & $\begin{array}{l}\text { 103. } 7^{\circ} \text {, Dama dama; } \\
\text { Megalocerotini s.s. }\end{array}$ \\
\hline 1 & $\begin{array}{l}\text { Angle between braincase roof and } \\
\text { braincase base }\end{array}$ & $\begin{array}{l}<25^{\circ} \ldots \text {... Megacerini } \\
>30^{\circ} \ldots \text {... Cervini }\end{array}$ & $16.55^{\circ}$, Megalocerotini s.I. \\
\hline 2 & Position of the anterior orbital rim & $\begin{array}{l}\text { over M2/M3 or M3...Megaloceros giganteus } \\
\text { over M2...other Megacerini }\end{array}$ & $\begin{array}{l}\text { At most over M2/M3, } \\
\text { Megalocerotini s.l. }\end{array}$ \\
\hline 4 & $\begin{array}{l}\text { Greatest skull width at the } \\
\text { posterior orbital rim }\end{array}$ & $46.9-59.1 \%$ of skull length...Megaloceros giganteus & $\begin{array}{l}\text { 48.93\%; Megaloceros } \\
\text { giganteus, Megalocerotini s.s. }\end{array}$ \\
\hline 6 & Foramen parietale & $\begin{array}{l}\text { Present...some Megacerini (e.g. Praemegaceros, } \\
\text { Orchonoceros, some Megaloceros giganteus), also } \\
\text { Dama dama }\end{array}$ & $\begin{array}{l}\text { Absent, Megalocerotini s.l. } \\
\text { which lack the foramen } \\
\text { parietale }\end{array}$ \\
\hline 8 & $\begin{array}{l}\text { Linea nuchae superior } \\
\text { (= "Occipital crest") }\end{array}$ & $\begin{array}{l}\text { Well-developed, arched between supraotic tubercules } \\
\text { from dorsal view...Megacerini } \\
\text { Trapezoid from dorsal view...Cervini }\end{array}$ & $\begin{array}{l}\text { Well-developed and slightly } \\
\text { arched, Megalocerotini s.I. }\end{array}$ \\
\hline 9 & $\begin{array}{l}\text { Angle between skull roof } \\
\text { and occipital plane }\end{array}$ & $\begin{array}{l}>90^{\circ} \ldots \text {... Megacerini } \\
<90^{\circ} \ldots \text { Cervini }\end{array}$ & $93.05^{\circ}$, Megalocerotini s.l. \\
\hline 11 & $\begin{array}{l}\text { Length of the paraoccipital } \\
\text { processes relative to occipital } \\
\text { condyles }\end{array}$ & $\begin{array}{l}\text { Shorter or slightly longer...Megacerini } \\
\text { Much longer...Cervini }\end{array}$ & Slightly longer, Megalocerotini s.I. \\
\hline 14.2 & $\begin{array}{l}\text { Bend of braincase baseline } \\
\text { between the basioccipital } \\
\text { and basisphenoid }\end{array}$ & $\begin{array}{l}>90^{\circ} \ldots \text { Megacerini } \\
=180^{\circ} / 0^{\circ} \ldots \text { Cervini }\end{array}$ & Obtuse, Megalocerotini s.l. \\
\hline
\end{tabular}

the foramen ovale, the length of the occipital, and measures obtained from the supraorbital region.

For 24 out of 36 measures, the coefficient of variation is below $8 \%$ (Table 3). This also holds for all but one variable, if we exclude the data of specimen 201, which, based on its distinct skull morphology (see description above), was classified as Candiacervus reumeri, whereas the five other rather complete skulls were classified as Candiacervus ropalophorus. For the relative orbit size, the exclusion of specimen 201 results in a reduction of the value of the coefficient of variation and the range of this variable becomes particularly homogeneous.

In Figure 5A, we contrast the six quantitative measures described by de Vos (1984: table 7) for his sample from Gerani 4 with the corresponding values obtained from our samples. Our data fall well within the range recorded by de Vos, although they tend to be on the smaller side, except for the two orbital measures DRC and DDV.

The length of the premolar and molar rows of the present specimens fall within the ranges defined by de Vos for his samples from Gerani 4 and Mavro Mouri 4c, i.e., the minima and maxima for these two sites are both smaller and larger, respectively, than those for our sample (Appendix 2). The length of the complete tooth row (P2M3) of the present specimens falls within the range defined by de Vos (1984) for a sample from Gerani 4.

In Figure 5B, we present the ratios of the length of the premolar rows and the molar rows of our sample and compare them with the ones reported by de Vos (1984: Fig. 2). The ratios of P2-P4/M1-M3 of specimens 201 and 5 (Appendix 1) fall just outside the $99 \%$ confidence interval as defined by the data shown in figure 2 of de Vos (1984), and reflect the relative small P2-P4 length.
When we compare the ranges of variation of the lengths of the premolar and molar tooth rows with the means of the respective variables reported by Simonelli (1908), we find that the premolar rows of our sample tend to be somewhat shorter, i.e., the mean of Simonelli's data does not fall within the range defined by the present measurements. In contrast, the molar rows of both samples seem to be of comparable length, i.e., the means of Simonelli's data are included in the ranges defined by our data (Appendix 2).

Finally, we performed a comparative analysis of our specimens along the lines of Vislobokova (2013). In her morphological characterization and classification of Megalocerotini Brookes, 1828 s.l., she had also included one specimen of Candiacervus IIb (de Vos 1984 or Candiacervus listeri van der Geer 2018; specimen AMPG (V)1734), and two specimens of Candiacervus ropalophorus (one from the MPUR, the other one from the NNML; specimen numbers are not reported). In Table 4, we summarize those characteristics defined by Vislobokova (2013) that could be measured or assessed in our sample. For most traits (13 out of 15), we find that the studied specimens of Candiacervus ropalophorus and $C$. reumeri resemble giant forms of cervids; specifically, nine characters, resemble Megalocerotini Brookes, 1828 s.l. and four other traits resemble Megalocerotini Brookes, 1828 s.s. When we scrutinize our sample for characters that had been used to differentiate various giant forms of cervids, we find that some traits are present in both, our sample and Praemegaceros; others traits present in our sample are identified also in Megaloceros, or even Cervus elaphus; for still other traits, no similarity could be reliably established (Table 5). Thus, we cannot identify any trend towards one specific member of Megalocerotini Brookes, 1828 neither s.l. nor s.s. 


\section{DISCUSSION}

In the present study, we describe some exquisitely preserved new skull remains of smaller-sized Cretan deer, i.e., Candiacervus ropalophorus de Vos, 1984 (= size 1, de Vos 1984), Candiacervus reumeri van der Geer, 2018 (= size 2, de Vos 1984), and Candiacervus sp.

\section{SYSTEMATIC ASSESSMENT OF THE SPECIMENS STUDIED}

Notwithstanding the uncertainties about the exact geological age of our specimens, they all can be unambiguously assigned to Candiacervus. We base this conclusion on the comparison of morphological characters of our specimens with those described for deer remains found in Gerani IV (de Vos 1984; Kuss 1975) and the Simonelli Cave (Malatesta 1980). Specifically, our specimens can be diagnosed as Candiacervus based on the following characters: cruciform nasals that do not contact the lacrimal bone and terminate rostrally or at the level of the rostral orbital rim. Orbits are round, with a thick dorsal orbital rim which rises above the frontal bone (Malatesta 1980). Ethmoidal gaps are small and alveolae for upper canines are absent. Preorbital depressions are absent. This latter finding is in contrast with previous observations, where weakly developed preorbital depressions are described, if somewhat cautiously, in rare individuals of Cretan deer (de Vos 1984; Kuss 1975; Simonelli 1908); however, figures in the respective papers do not allow for a clear or unambiguous identification. Kuss (1975) noted that young females lacked a depression and that older females had weakly developed depressions. For young males, Kuss (1975) noted the absence of the preorbital depression. The absence of the depressions, as noted in our sample, sets Candiacervus apart from all extant cervids (Schilling et al. 2019), and also from members of the extinct giant forms of cervids (Megaloceros- and the Praemegacerosgroup (Vislobokova 2013)). The most plausible explanation for these discrepancies is that Candiacervus lost the depression when adapting to the insular environment.

We could assign five of our specimens (1972 XIX 1, 1972 XIX 200, 1972 XIX 202, 1972 XIX 203, 1972 XIX 204) to the smallest size group defined by de Vos (1984), i.e., Candiacervus ropalophorus (Figs 1; 2; 3A-E). These five specimens, as all members of this size group, have a skull type "a" as defined by de Vos (1984), with round orbits, a thick dorsal orbital rim, an at most weakly developed interfrontal crest and a P2 of "morphotype 1", i.e., protocone and metaconule are of similar size (de Vos 1984). Our quantitative analyses support this latter classification. We used the same variables as de Vos (1984: table 7), and our data fall within those of his specimens from Gerani IV (Figure 9) - a site, where apparently nearly all individuals belonged to Candiacervus ropalophorus (99\% of the material; de Vos 1984). Both males are early adults as confirmed by dentition status (early to no wear and M3s in eruption). 1972 XIX 203 is from a yearling, because it lacks a burr at the proximal end of its left antler. Crests at the base of the pedicles could not be discerned, which contrasts with previous findings on adult, mature specimens, where such crests are strongly developed (Kuss 1975; Vislobokova 2013).

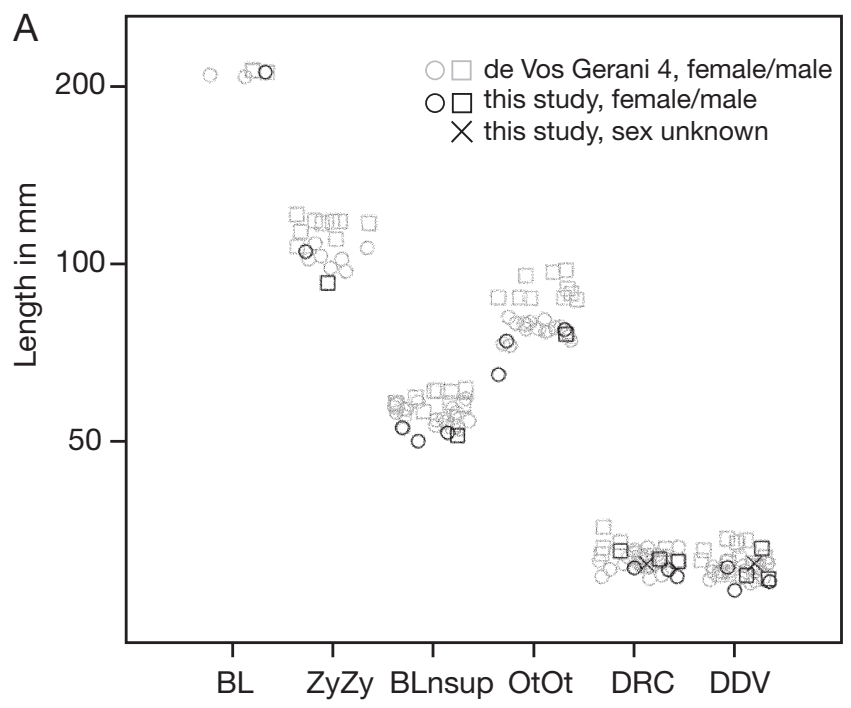

Measure

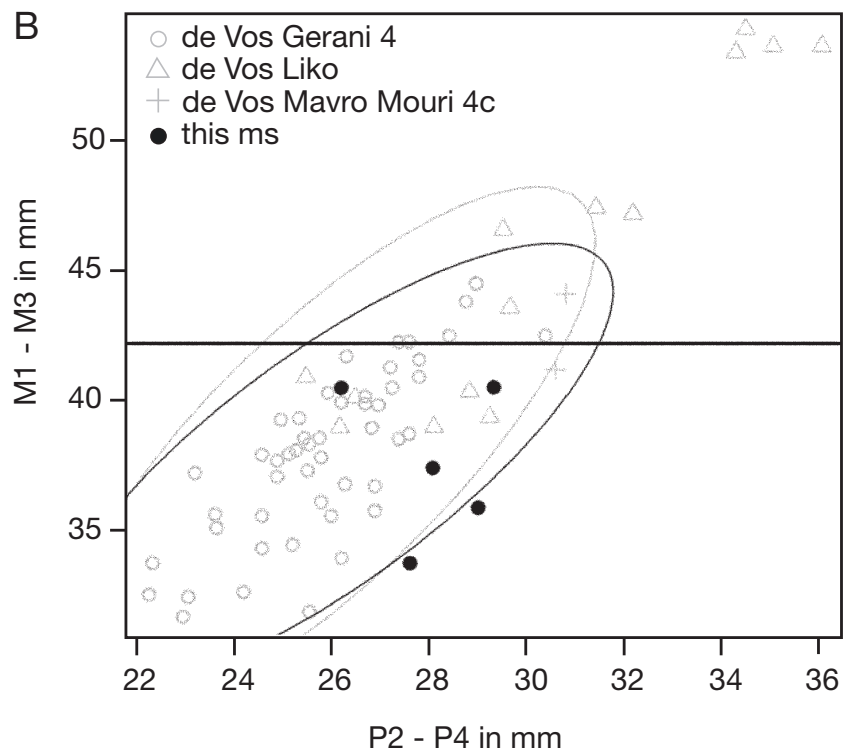

FIG. 5. - A, Skull measurements obtained with the present sample (in black) compared to those reported by de Vos (1984) (in grey). The skull measures defining our sample lie within the range of the sample from Gerani 4 of de Vos, although they tend to be on the smaller side. Abbreviations: BL, basilar length; ZyZy, bizygomatic width; BLnsup, height of the linea nuchae superior to the basion; OtOt, width of the occipitale; DRC, rostrocaudal diameter of the orbit; DDV, dorsoventral diameter ('height') of the orbit. Data of de Vos (1984) are taken from his table 7. B. The relation between the length of premolar rows (P2-P4) and the length of the molar rows (M1-M3) in our sample (in black), contrasted with those reported by de Vos (1984) for different sites (in grey). Data of de Vos are extrapolated from his figure 2 and taken from his table 2. The horizontal line represents cases for which P2-P4 are not available, and the data for M1-M3 are so similar that lines coincide. The ellipses show the $99 \%$ confidence interval $(\mathrm{Cl})$ for our sample (in black) and the C. ropalophorus de Vos, 1984 sample from Gerani 4 described by de Vos (in grey). The ellipses were calculated based on standard deviations. Three specimens fall within the space where the two Cls intersect and could be identified as $C$. ropalophorus. SNSB-BSPG 1972 XIX 201 and SNSB-BSPG 1972 XIX 5 (C. reumeri van der Geer, 2018 and Candiacervus sp., respectively) fall just outside the given Cls. 
In 1972 XIX 200, the right distal pedicle plus antler as well as largest portion of left antler are missing; however, a minimal burr with some pearls is preserved. The burr indicates that 1972 XIX 200 is somewhat older than 1972 XIX 203. This interpretation is also supported by the finding that in 1972 XIX 200, the eruption stage of the 3rd molar is a later one than in 1972 XIX 203. Still, the small size and the simplicity of the burr - which is hardly more than a ring of bony pearls - suggest, in addition to eruption stage of the right 3rd molar, that 1972 XIX 200 is also from a quite young individual with a second antler generation. In fact, the structure of the burr observed here is even simpler than that of the most immature burrs described for Candiacervus (Kuss 1975): This author defined four stages of antler development, with a well-developed burr composed of bony pearls present already in the first stage.

Based on our quantitative measures, the two early adult males (Figs 1F-I; 2F-I) cannot be told apart from older adult females (Fig. 5A). An exception to this is the bizygomatic width (ZyZy): For one early adult male, 1972 XIX 203, this distance is smaller than that of one older adult female of our sample and that of the adult males and females of the sample of de Vos (1984).

1972 XIX 201 differs from the five C. ropalophorus specimens. Its thin dorsal orbital rims and a P2 characterized by unequally sized protocone and metaconule ("morphotype 2", de Vos (1984)), indicate that this specimen is probably of skull type "d" (= Candiacervus IIc, de Vos 1984) or Candiacervus reumeri van der Geer, 2018. Another notable difference of this $C$. reumeri specimen compared with $C$. ropalophorus is that in the former the maxilla directly contacts the frontal bone above the ethmoidal gap. Differently sized foramina supraorbitalia, as observed in this $C$. reumeri specimen, have been noted before in specimens of Candiacervus cretensis. Thus, this appears to be a quite labile character in Cretan deer. The quantitative measures we could obtain for $C$. reumeri are less diagnostic than its qualitative characters described above. For example, the length of the molar tooth row of the present $C$. reumeri specimen $(62.9 \mathrm{~mm})$ falls within the overlap between size A, typical for $C$. ropalophorus and size B, typical for Candiacervus II. i.e., C. listeri, C. devosi or C. reumeri (62.7 - $71.7 \mathrm{~mm}$; de Vos 1984: table 10).

The fact that the site close to Gerani, where our sample was collected, yielded C. ropalophorus and C. reumeri is in line with previous reports of better-known sites, i.e., Gerani IV, Mavro Mouri 4c, Rethymnon fissure, Sourida, and Kalo Chorafi (see e.g. de Vos 1984), where the two species also coexisted. While qualitative, morphological characters allow distinguishing these sympatric species, our quantitative data, even when considered together with those of de Vos (1984: tables 2 and 7), are not discriminative. Potential exceptions might be the relative orbit size, which is clearly smaller for the one $C$. reumeri than for the $C$. ropalophorus specimens analyzed here, and the relative length of the molar and premolar tooth rows. The ranges of variation of the premolar and molar row of our specimens fall within the ranges for samples from Gerani IV and Mavro Mouri 4c (de Vos 1984)
(Appendix 2). However, when we consider the relationship between the premolar and the molar row length (Fig. 5B), C. reumeri falls outside the confidence interval defining C. ropalophorus specimens, together with one of the specimens for which a species assignment was not possible, Candiacervus $s p$. (SNSB-BSPG 1972 XIX 5). In contrast, all three of our C. ropalophorus specimens for which this ratio could be obtained fall well within the confidence interval defined by the C. ropalophorus specimens from Gerani 4 (de Vos 1984). That said, we add that this observation is based essentially on a single specimen of $C$. reumeri. Thus, it is at best a clue for further studies, but certainly does not yet define a unique feature to tell apart Candiacervus species.

The conclusion that, so far, quantitative data do not allow to discriminate $C$. ropalophorus from $C$. reumeri is also supported by the few quantitative measures that are common to our analysis and those of Malatesta (1980) and Simonelli (1908) for skull specimens from Simonelli Cave, which were identified as Praemegaceros cretensis by Malatesta (1980), and as Candiacervus reumeri by van der Geer (2018). These include the orbital width and height and the greatest skull width (Malatesta's variables "i", " $\mathrm{n}$ " and "o" in his table 1; our variables 5, 6 and 10; Table 2). The ranges for the orbital measure fully overlap. The greatest skull diameter reported by Malatesta is somewhat smaller $(102-106 \mathrm{~mm} ; \mathrm{n}=4)$ than that observed for $C$. ropalophorus presently (110-114 mm; Table 3). The comparison of these data is limited by the fact that Malatesta's report allows to extract information on the sex from only four specimens he studied: these bear pedicles and thus can be identified as males. Further, the age of the specimens analyzed by Malatesta has not been reported, but may be tentatively discussed as follows: the four figured specimens are adults, for one specimen (Malatesta 1980: plate II) none of the cheek teeth is preserved and the developmental stage can only be inferred by the presence of alveolae of permanent teeth. The remaining three specimens have an erupted M3, occlusal surfaces are generally more heavily worn than in our two early adult males and specifically, the dentine of the paracone of $\mathrm{M} 2$ is in contact with the dentine of the protocone (Malatesta 1980: plate III; IV), indicating a more advanced age of the specimens from Simonelli Cave. Hence, our males and those of Malatesta (1980) do not allow for direct comparison and a (supporting) assessment of our C. ropalophorus specimens.

The comparison of our data on the premolar and molar rows with that of Simonelli does not allow for any sound interpretation given the extremely small sample sizes, especially for Simonelli's data (2 specimens).

\section{Cranial CHARaCter STATES OF Megalocerotini}

BROOKES, 1828 S.L. IN CANDIACERVUS

Our results also confirm previous findings (e.g. Azzaroli 1852; Caloi \& Palombo 1994; Radulescu \& Samson 1967; Sondaar \& Boekschoten 1967) that the Candiacervus skull shares several character states with Megalocerotini Brookes, 1828 s.l. Four of these general characters need particular attention (character IDs according to Vislobokova (2013) are given in brackets; see also Table 4): 
TABLE 5. - Diagnostic traits to discriminate members of Megalocerotini, Brookes, 1828 s.l. (Croitor 2016) applied to Candiacervus. Traits were taken from Vislobokova (2013).

\begin{tabular}{|c|c|c|c|}
\hline \multicolumn{3}{|r|}{ Vislobokova 2013} & \multirow[b]{2}{*}{$\begin{array}{l}\text { Results for Candiacervus } \\
\text { in this study }\end{array}$} \\
\hline Character ID & $\begin{array}{l}\text { Character name/ } \\
\text { description }\end{array}$ & Discrimination & \\
\hline 1.1 & $\begin{array}{l}\text { Forehead structure and } \\
\text { position of pedicles }\end{array}$ & $\begin{array}{l}\text { Convex forehead, interantler eminence distinct, interfrontal suture strongly } \\
\text { developed, pedicles directed posterolaterally, angle between the aboral } \\
\text { edge of the pedicle and skull roof }<90^{\circ} . . \text { Megaloceros-group } \\
\text { Flat forehead, interantler eminence indistinct, interfrontal suture weakly } \\
\text { developed; pedicles diverging, directed laterally, and widely spaced, } \\
\text { angle between the aboral edge of the pedicle and skull roof } \\
\text { c. } 90^{\circ} \ldots \text { Praemegaceros-group }\end{array}$ & Praemegaceros-group \\
\hline 1.2 & $\begin{array}{l}\text { Shape of the supraorbital } \\
\text { foramen and } \\
\text { supraorbital groove }\end{array}$ & $\begin{array}{l}\text { Large supraorbital foramen, irregularly rounded, deep supraorbital } \\
\text { groove with the supraorbital foramen at its external edge, diameter } \\
\text { foramen /width of groove } c .0 .5 \ldots \text { Megaloceros } \\
\text { Supraorbital foramen smaller and shallower supraoccipital groove than } \\
\text { in Megaloceros ... Praemegaceros } \\
\text { Supraorbital groove deep and widened in the middle part, large } \\
\text { foramen at the external edge... Candiacervus }\end{array}$ & $\begin{array}{l}\text { Megaloceros? } \\
\text { Praemegaceros? }\end{array}$ \\
\hline 2.1 & $\begin{array}{l}\text { Angle between skull roof } \\
\text { and occiput }\end{array}$ & $\begin{array}{l}>90^{\circ} \ldots \text { ancestral megacerines (Arvernoceros, Orchonoceros) } \\
=90^{\circ} \ldots \text { advanced megacerines (Praemegaceros, Megaloceros) }\end{array}$ & Ancestral megacerins \\
\hline 3 & $\begin{array}{l}\text { Fossae lateral to } \\
\text { interantler eminence }\end{array}$ & $\begin{array}{l}\text { Weakly developed... Megaloceros; } \\
\text { Well-developed... Praemegaceros, Orchonoceros, Arvernoceros }\end{array}$ & Megaloceros \\
\hline 4.1 & $\begin{array}{l}\text { Position of the occipital } \\
\text { condyles }\end{array}$ & $\begin{array}{l}\text { Occipital condyles project strongly posteriorly... Praemegaceros, } \\
\text { Orchonoceros } \\
\text { Occipital condyles project moderately posteriorly... Megaloceros }\end{array}$ & none \\
\hline
\end{tabular}

\section{(1) Angle between the forehead}

and the dorsal surface of the braincase

Our C. ropalophorus specimens have steeper foreheads than Megalocerotini Brookes, 1828 s.l. and with respect to this character, are most similar to Dama (Linnaeus, 1758). Similarities with this genus have been proposed based on the antler morphology of the smaller-sized Candiacervus species, to which C. ropalophorus belongs (van der Geer 2018). In contrast to our data, Vislobokova (2013) reports the angle for $C$. listeri $\left(120^{\circ}\right)$, a species assigned to size group 2 sensu de Vos (1984) (Table 1). For the present C. reumeri, another species of size group 2 , this character cannot be assessed.

\section{(2) Position of the rostral orbital rim}

In small and short-faced living cervid species (e.g. Muntiacus, Capreolus, Mazama, and Pudu), the rostral orbital rim is positioned above M1/M2. In larger cervids with longer faces (e.g. Alces and Cervus, but also Megaloceros), the rostral orbital rim is positioned above M3. In our specimens that are from rather small animals, the rostral orbital rim is located above M2 or M2/M3. Thus, we may infer that they tended to have relatively long faces compared with small, extant cervids. This is also indicated by the rather long face $(55.7 \%$ of the condylobasal length) of SNSB-BSPG 1972 XIX 1, the only one in which the snout is preserved. Relative to the condylobasal length, the face is thus longer than that of Praemegaceros cazioti, the dwarfed cervid from Sardinia (49.7\%; Croitor 2016: Table 2). However, Candiacervus had a shorter face than the large-sized Cervus elaphus, Praemegaceros obscurus and Megaloceros giganteus (> 57\%; Croitor 2016: Table 2).

\section{(4) Greatest skull width}

For the one complete skull of $C$. ropalophorus we could analyze (SNSB-BSPG 1972 XIX 1), the skull width is $48.9 \%$ of the skull length and falls within the range defined for Megalocerotini Brookes, 1828 s.s. The greatest skull width of our specimens was found to be at the caudal orbital border (Figs 1A, F; 2F; 3A, F). This contrasts with Vislobokova (2013), who states that the greatest skull width of Candiacervus is at the orbital center and that this distinguishes Candiacervus from other giant forms of cervids, where it is at the caudal orbital border. Thus, our data add yet another morphological similarity between Candiacervus and giant forms. However, we would like to stress that this finding may be interpreted as a habitat-related apomorphic character, as the position of the widest skull breath relates to the inclination of the orbits in the sagittal plane (see below, 5.3, discussion on the inclination of the orbits). Finally, we would like to point out that the location of the greatest skull width in Candiacervus at the caudal orbital border may also be recognized in figure 11c of Vislobokova (2013).

\section{(14.2) Bend of the braincase baseline between the basioccipital and basisphenoid}

The angle is obtuse in our sample from older females, as it is also in Megalocerotini Brookes, 1828 s.l. In the one early adult male (1972 XIX 203) where we could measure it, the two bones are in one plane, as diagnosed by Vislobokova (2013) for Cervus and close relatives. This may reflect a developmental phenomenon, as Meunier (1963) observed that the bend is absent in reindeer calves and develops postnatally. Alternatively, it might be a sex difference reflecting the greater load on the atlanto-occipital joint that should result from antlers (cf. Vislobokova 2013). 
For other characters, our sample may be compared with members of Megalocerotini s.l., but also, with some restrictions, to Megalocerotini s.s. For instance, for C. ropalophorus, the ratio between the diameter of the foramen supraorbitale and the supraorbital groove (character ID 1.2, Table 5) observed in our $C$. ropalophorus specimens is comparable with that seen in Megaloceros (c. 0.5, Appendix 1; Vislobokova (2013)). In contrast, the supraorbital groove of $C$. ropalophorus is relatively shallow, reminiscent of Praemegaceros. Despite the larger ratio between the diameter of the foramen supraorbitale and the supraorbital groove, the present $C$. reumeri specimen resembles Megaloceros in having deep, sharp-edged orbital grooves. In the two males of our sample, the relatively weakly developed muscular tubercles of the basioccipital (Fig. 2I) and the more rostral extension of the pterygopalatine fossa (Figs 1I; 2I) might be linked to their relatively young age.

While the comparison of our sample with that described by Vislobokova (2013) is somewhat limited due to e.g. specimen incompleteness, our data confirm, for most of the traits (Table 5), similarities between Candiacervus and Megalocerotini Brookes, $1828 \mathrm{~s}$ s. . This observation is based on a larger sample set than that of Vislobokova, as we include C. reumeri, which had not been analyzed along the lines defined by Vislobokova before. However, we think that such similarities cannot be confidently interpreted in a phylogenetic context; hence, the mainland relatives, or ancestors, of Candiacervus remain elusive. We propose that the most plausible explanation of the ambiguous nature of some traits may have resulted from the secondary size reduction of Candiacervus ropalophorus and $C$. reumeri.

In fact, distinct variations of a number of morphological traits in the Candiacervus skull, or rather its predecessor(s), resulting from insular dwarfing on Crete, may have "obscure[d] affinities with any other known taxon; many such groups [that have undergone dwarfism] are taxonomic enigmas" (Hanken \& Wake 1993: 510).

Morphological consequences of dwarfing are, among others: 1) a reduction and structural simplification; and 2) an increased morphological variability (Hanken \& Wake 1993). The first consequence can manifest itself as a reduced development or even a complete loss of structures or organs. Thus, the lack of preorbital depressions as observed presently in both C. reumeri and C. ropalophorus results from a simplification of the lacrimal bone housing this depression. A reduction of the preorbital depression has also been noted in Praemegaceros cazioti from Sardinia (Croitor et al. 2006). In extant cervids, the preorbital depression hosts the preorbital gland, which is used for intraspecific communication (Mattioli 2011). The absence of the depression in Candiacervus (and presumably in Praemegaceros, see e.g. Vislobokova (2013: figs 54, 55); Croitor et al. (2006: fig. 2)) suggests that also the preorbital glands were likely reduced in these species, maybe even lacking. Indeed, it has been argued that the reduction of the preorbital depression might be correlated with decreased olfactory capacities of island deer (Croitor et al. 2006).

In most, if not all, extant cervids, the braincase is longer than wide. This holds also for cervid fossils (Croitor 2018). If this was also so in the unknown ancestor of Candiacervus, any changes in braincase length and width during dwarfing must have occurred to different degrees, as these two measures are about equal in Candiacervus. This is fully consistent with the observation of Palombo et al (2008), that brain size in Candiacervus is little affected by dwarfing: as the side lengths of its braincase approach equality, its overall volume gets optimized with respect to its surface size to house a brain of "minimal size needed according to environmental conditions" (Palombo et al. 2008: p. 178). The relatively short braincase, together with the rostrally displaced occipital condyles also result in a mechanical optimization to carry the long antlers present in Candiacervus (Strasser et al. 2018; van der Geer 2018).

The lack of upper canine alveolae, and consequently the upper canine teeth, is another structural reduction. The second consequence of dwarfing, i.e., an increased morphological variability, is manifested, in our sample, by a variety of traits (see those with a CV > 8 in Table 3), notably the morphology of the supraorbital foramen and groove. This variability is yet another factor that limits the use of these traits for the reconstruction of phylogenetic relationships between Candiacervus and mainland deer.

\section{THE HABITAT OF CANDIACERVUS}

REVEALED BY SKULL CHARACTERISTICS

Other cranial particularities described presently for Cretan deer and discussed in the light of its relationship with mainland deer give hints on the ecology of $C$. ropalophorus. For instance, the rectangular outline of the premaxilla, observed in specimen 1 (Fig. 1D), has been reported previously for Candiacervus IIb sensu de Vos (1984) (now Candiacervus devosi van der Geer, 2018)) and linked to a large proportion of herbs in the diet (Vislobokova 2013). In addition, a slightly obtuse angle between the skull roof and the occiput (Appendix 1) as well as the rostrally displaced occipital condyles relative to the most caudal point of the occiput has also been observed in Praemegaceros verticornis (Dawkins, 1872) and Megaloceros and has been interpreted as an adaptation to mixed feeding (Vislobokova 2013).

The inclination of the orbits relative to the median skull plane has been used to infer habitat preferences in cervids. Specifically, large angles, as found in Candiacervus (Appendix 1), have been suggested as indicative for open habitats (Vislobokova 2013), but also as a reduced need to avoid predators (Welker et al. 2014). The better stereoscopic view, afforded by the more anterior orientation of the eyes, has been interpreted as secondarily derived trait typical for island dwellers (van der Geer 2005). It also implicates a reduced field of view. The rather small size of the orbits (their widths equal $13.6 \%$ of the condylobasal length, Table 3 ) is reminiscent of what has been described for the insular Praemegaceros cazioti (14.7\%, Croitor 2016: table 2). The concurrence of this finding in these two insular cervids suggests that this may be yet another adaptation to the insular environment. The probable changes in the sense of smell (see above) and vision in Candiacervus would be well in line with the notion that this cervid was living in a predator-free environment (Palombo et al. 2008; van der Geer 2018; van der Geer et al. 2014). 
Finally, the relative timing of the eruption of the third molar might give insights into habitat preferences. In cervids, the lower premolars typically erupt after the third molar (Veitschegger \& Sánchez-Villagra 2016). This has been said to be also true for Candiacervus (van der Geer et al. 2014), although it is not clear how this conclusion was arrived at. Our material allows, for the first time, to directly time the eruption of the third molar in the maxilla. Systematic data on the eruption sequences of maxillary teeth are not available yet, but Smith (2000: p. 213) noted that the "eruption order [of the permanent dentition in eutherians] is similar in the maxilla and mandible. This is also supported by the present understanding of principles of mammalian dentition and the functional morphology of the mastication apparatus (e.g. Ungar 2010). Specifically, the timing of eruption of upper and lower teeth has been observed to be very similar in cervids (Seo et al. 2017; Severinghaus 1949), as also in other ruminants (Hemming 1961; Dow \& Wright 1962; Węgrzyn \& Serwatka 1984). Thus, it seems justified to assume that the eruption sequence in the maxilla is the same as in the mandibula in cervids. The fact that M3 is the last tooth to erupt in the maxilla of Candiacervus ropalophorus sets it apart from most other cervids, except for a Spanish population of red deer (C. elaphus Linnaeus, 1758), where a similar pattern has been described (Azorit et al. 2002), and Newfoundland caribou, in which $\mathrm{m} 3$ and the premolars erupt about simultaneously (Bergerud 1970). More intriguingly, this trait parallels the pattern observed in some bovid caprines (Capra Linnaeus, 1758, Hemitragus Hodgson, 1833, Nilgiritragus Ropiquet \& Hassanin, 2005, and Ovis Linnaeus, 1758), where $\mathrm{m} 3$ erupts after $\mathrm{p} 4$ in the lower jaw. This has been interpreted as an adaptation to resource availability in high elevation habitats (Monson \& Hlusko 2018). Lastly, we caution that we cannot exclude that the eruption of M3 as last tooth in the two Candiacervus males in our sample is a case of intraspecific variability. Yet no data are available to follow up on this idea.

The dental eruption pattern is yet another trait of Candiacervus reminiscent of goats. Previously, the limb morphology and also the relatively simple antlers have led to comparisons with goats and functionally, this has been interpreted as indicating that $C$. ropalophorus and $C$. devosi probably occupied a rocky environment, as does the Cretan wild goat, Capra aegagrus (van der Geer et al. 2006a). Our data are fully in line with this and show that Candiacervus adapted also towards the rather poor diet that goats may typically live on.

\section{CONCLUSIONS}

Our detailed morphological and morphometric study on some new, exquisitely preserved craniodental material of Cretan deer reveal affiliations to the two smaller-sized Candiacervus species, C. ropalophorus and $C$. reumeri (size group I and II, respectively, according to de Vos (1984)), documenting a further record of sympatry of both species. In addition, our data show for the first time a specific tooth replacement pattern and the absence of a preorbital depression, both extremely rare within Cervidae, as well as a clearly longer snout than in other small cervids; taken together, these particularities might constitute distinctive character states of Candiacervus specimens. Moreover, we can document that the basioccipital and basisphenoid are arranged in different angles, on the one hand, in females and, on the other hand, in the one male available.

Morphological comparison to assess the relatedness of Candiacervus within Megalocerotini Brookes, 1828 s.l. and s.s. provide an extended evidence that Candiacervus and extinct giant forms of cervids share many similarities. However, more material is needed to interpret characters in terms of intraspecific variation, development, and sexual dimorphism; a multivariate cluster analysis might help to put the morphological comparison of Candiacervus with its suspected relatives and/ or ancestors on a more formal footing.

Our data complement the previous findings on morphometric specifics in Candiacervus that match what has been called the "island dwarfing syndrome" (Croitor et al. 2006, p. 35-36). Particularly, our data strengthen the hypothesis that small-sized Candiacervus species adapted to niches specific to goats. Finally, we have to conclude that, while the adaptive characteristics of Candiacervus described here provide more insight into its life in harsh, insular environment, they also blur ancestral traits and constitute a major impediment for reliably relating this cervid to its ancestors and mainland relatives.

\section{Acknowledgements}

We are grateful to Judith Braukämper (SNSB-BSPG), Elisabeth Lange (SNSB-BSPG), and Stefan Sonyi (SNSBBSPG) for specimen preparation, Manuela Schellenberger (SNSB-BSPG) for photographs, Dr H.-J. Gregor (Olching) for describing and discussing details of the site from where he collected the specimens. Bastien Mennecart (Basel) provided French translation. We would like to thank two anonymous reviewers for their constructive comments that helped us to improve the manuscript. We also would like to thank the associate editor, L. Rook. This research did not receive any specific grant from funding agencies in the public, commercial, or not-for-profit sectors.

\section{REFERENCES}

ACCORDI B. 1972. - Lo scavo della "Grotta Simonelli" con cervi nani del Quaternario, effettuato a Creta nel 1971 dall'Istituto di Geologia e Paleontologia dell'Università di Roma con il finanziamento dell'Accademia Nazionale dei Lincei. Quaderno dell'Accademia nazionale dei Lincei 167: 1-17.

AMsOn E. \& KolB C. 2016. — Scaling effect on the mid-diaphysis properties of long bones-the case of the Cervidae (deer). The Science of Nature 103: 58. https://doi.org/10.1007/s00114-016-1379-7

ATTARD I. R. \& REUMER J. 2009. - Taphonomic reinterpretation of a bone sample of endemic Pleistocene deer from Crete (Greece): osteoporosis versus regurgitation. Palaeodiversity 2: 379-385.

AzZAROLI A. 1952. — La sistematica dei cervi giganti e i cervi nani delle isole. Atti della Società Toscana di Scienze Naturali, Memorie (A) 59: 119-127. 
Azorit C., Analla M., Carrasco R., Calvo J. A. \& MunozСово J. 2002. - Teeth eruption pattern in red deer (Cervus elephus hispanicus) in southern Spain. Anales de Biologia 24: 107-114.

Bergerud A. 1970. - Eruption of Permanent Premolars and Molars for Newfoundland Caribou. The Journal of Wildlife Management 34: 962-963. https://doi.org/10.2307/3799172

Caloi L. \& Palombo M. R. 1990. - Gli Erbivori Pleistocenici Delle Isole Del Mediterraneo: Adattamenti. Hystrix 2: 87-100.

Caloi L. \& Palombo M. R. 1994. - Functional Aspects and Ecological Implications in Pleistocene Endemic Herbivores of Mediterranean Islands. Historical Biology 8: 151-172. https:// doi.org/10.1080/10292389409380475

Caloi L. \& Palombo M. R. 1995. - Functional aspects and ecological implications in Pleistocene endemic cervids of Sardinia, Sicily and Crete. Geobios 28: 247-258. https://doi.org/10.1016/ S0016-6995(95)80231-2

Caloi L. \& Palombo M. R. 1996. - Functional aspects and ecological implications in Hippopotami and cervids of Crete, in REESE D. S. (ed.), Pleistocene and Holocene Fauna of Crete and Its First Settlers. Monographs in World Archeology 28: 125-151. https://doi.org/10.1080/10292389409380475

CAPASSO BARBATO L. 1989. - Cervidi endemici del Pleistocene di Creta. Unpublished PhD thesis, Modena, Bologna, Firenze, Roma, 214 p.

Capasso Barbato L. 1990. - Les cervidés endémiques de Crète. Quaternaire 1: 265-270. https://doi.org/10.3406/quate.1990.1943

Capasso Barbato L. 1992. - Nuova specie di Cervide del Pleistocene di Creta. Atti della Accademia Nazionale dei Lincei. Classe di Scienze Fisiche, Matematiche e Naturali 1: 183-220.

CAPASSO BARBATO L. 1995. - Un tentativo di analisi cladistica applicata ad un cervide endemico del Pleistocene di Creta. Geologica Romana 31: 243-248.

Capasso Barbato L. \& Petronio C. 1986. - Cervus major n. sp. of the Bate Cave (Rethymnon, Crete). Atti della Accademia Nazionale dei Lincei, Memorie 18: 59-100.

Carlquist S. J. 1974. - Island Biology, First edition. Columbia University Press, New York: 660 p. https://doi.org/10.5962/ bhl.title.63768

Croitor R. 2014. - Deer from late Miocene to Pleistocene of western Palearctic: Matching fossil record and molecular phylogeny data. Zitteliana B, 32: 115-153. https://doi.org/10.5282/ UBM/EPUB.22391

Croitor R. 2016. - Systematical position and paleoecology of the endemic deer Megaceroides algericus Lydekker 1890 (Cervidae, Mammalia) from the late Pleistocene-early Holocene of North Africa. Geobios 49: 265-283. https://doi.org/10.1016/j. Geobios.2016.05.002

Croitor R. 2018. - Plio-Pleistocene Deer of western Palearctic: Taxonomy, Systematics, Phylogeny. Institute of Zoology of the Academy of Sciences of Moldova, Chisinău, 140 p.

Croitor R., Bonifay M.-F. \& Bonifay E. 2006. - Origin and evolution of the Late Pleistocene island deer Praemegaceros (Nesoleipoceros) cazioti (Depéret) from Corsica and Sardinia. Bulletin du Musée d'Anthropologie préhistorique Monaco 46: 35-68.

Davis E. B., Brakora K. A. \& LeE A. H. 2011. — Evolution of ruminant headgear: A review. Proceedings of the Royal Society $B$. Biological Science 278: 2857-2865. https://doi.org/10.1098/ rspb.2011.0938

DE VOS J. 1979. - The endemic Pleistocene deer of Crete. Proceedings of the Koninklijke Nederlandse Akademie van Wetenschappen, $B$ 82: $59-90$

DE VOS J. 1984. - The endemic Pleistocene deer of Crete. Verhandelingen der Koninklijke Nederlandse Akademie van Wetenschappen 31: 1-100.

DE Vos J. 2000. - Pleistocene Deer Fauna in Crete: Its Adaptive Radiation and Extinction. Tropics 10: 125-134. https://doi. org/10.3759/tropics. 10.125
De Vos J. \& van der Geer A. A. E. 2002. - Major Patterns and Processes in Biodiversity: taxonomic diversity on islands explained in terms of sympatric speciation, in WALDREN B. \& ENSENYAT J. A. (eds), World Islands in Prehistory, International Insular Investigations, $V$ Deia International Conference of Prehistory. British Archaeological Reports (BAR) International Series 1095, Oxford: 395-405.

Dow S. A. \& Wright P. L. 1962. - Changes in Mandibular Dentition Associated with Age in Pronghorn Antelope. The Journal of Wildlife Management 26: 1-18. https://doi. org/10.2307/3798162

FLOWER W. H. 1883. - On the arrangement of the orders and families of existing Mammalia. Proceedings of the Zoological Society of London Vol. 51: 178-186. https://www.biodiversitylibrary. org/page/28679980

GoldFuss G. A. 1820. - Handbuch der Zoologie; Erste Abteilung. J. L. Schrag, Nürnberg, $696 \mathrm{p}$.

HANKEN J. \& WAKE D. B. 1993. - Miniaturization of body size: Organismal consequences and evolutonary significance. Annual Review of Ecology and Systematics 24: 501-519. https://doi. org/10.1146/annurev.es.24.110193.002441

Hemming J. E. 1961. - Mandibular dentition and horn development as criteria of age in the Dall sheep Ovis dalli Nelson 1884. Master thesis, University of Montana, Missoula. https://scholarworks. umt.edu/etd/6503

Hughes S., Hayden T. J., Douady C. J., Tougard C., Germonpré M., Stuart A., Lbova L., Carden R. F., HänNi C. \& SAY L. 2006. - Molecular phylogeny of the extinct giant deer, Megaloceros giganteus. Molecular Phylogenetics and Evolution 40: 285-291. https://doi.org/10.1016/j.ympev.2006.02.004

Iliopoulos G., EIKAMP H. \& FASSOULAS C. 2010. - A new Late Pleistocene mammal locality from western Crete. Bulletin of the Geological Society of Greece 43: 1-7. https://doi.org/10.12681/ bgsg. 11257

Immel A., Drucker D. G., Bonazzi M., Jahnke T. K., MünZel S. C., Schuenemann V. J., Herbig A., Kind C. J. \& KRAUSE J. 2015. - Mitochondrial genomes of giant deers suggest their late survival in central Europe. Scientific Reports 5: 1-9. https://doi.org/10.1038/srep10853

Kolb C., Scheyer T. M., Lister A. M., Azorit C., De Vos J., Schlingemann M. A. J., Rössner G. E., Monaghan N. T. \& SÁNCHEZ-Villagra M. R. 2015. - Growth in fossil and extant deer and implications for body size and life history evolution. BMC Ecology and Evolution 15: 19. https://doi.org/10.1186/ s12862-015-0295-3

Kuss S. E. 1965. — Eine pleistozäne Säugetierfauna der Insel Kreta. Berichte der Naturforschenden Gesellschaft zu Freiburg im Breisgau 55: 271-348.

KusS S. E. 1970. - Abfolge und Alter der pleistozänen Säugetierfaunen der Insel Kreta. Berichte der Naturforschenden Gesellschaft zu Freiburg im Breisgau 60: 35-83.

Kuss S. E. 1973. - Die pleistozänen Säugetierfaunen der ostmediterranen Inseln. Ihr Alter und ihre Herkunft. Berichte der Naturforschenden Gesellschaft zu Freiburg im Breisgau 63: 49-71.

KusS S. E. 1975. — Die pleistozänen Hirsche der ostmediterranen Inseln Kreta, Kasos, Karpathos und Rhodos (Griechenland). Berichte der Naturforschenden Gesellschaft zu Freiburg im Breisgau 65: 25-79.

LAX E. M. 1991. - A Gazetteer of Pleistocene Paleontological Sites on Crete Island, Greece. The University of Arizona. http://hdl. handle.net/10150/558152

LAX E. M. 1996. - A gazetteer of Cretan paleontological localities, in REESE D.S. (ed.), Pleistocene and Holocene Fauna of Crete and Its First Settlers. Prehistory Press, Madison (Wisconsin): 1-32.

LEINDERS J. J. M. \& HeINTZ E. 1980. - The configuration of the lacrimal orifices in Pecorans and Tragulids (Artiodactyla, Mammalia) and its significance for the distinction between Bovidae and Cervidae. Beaufortia 30: 155-160. 
Lister A. M., Edwards C. J., Nock D. A. W., Bunce M., Van Pijlen I. A., Bradley D. G., Thomas M. G. \& Barnes I. 2005. The phylogenetic position of the "giant deer" Megaloceros gigan teus. Nature 438: 850-853. https://doi.org/10.1038/nature04134

Losos J. B. \& RicKLEFS R. E. 2009. - Adaptation and diversification on islands. Nature 457: 830-836. https://doi.org/10.1038/ nature 07893

Malatesta A. 1980. - Dwarf Deer and Other Late Pleistocene Fauna of the Simonelli Cave in Crete. Accademia nazionale dei Lincei 1: 1-128. https://doi.org/10.1145/2505515.2507827

MatTioli S. 2011. — Family Cervidae (Deer), in Wilson D. E. \& MitTermeier R. A. (eds), Handbook of the Mammals of the World. Lynx Ediciones, Barcelona: 350-428.

Mazza P., Rossi M. A., Rustioni M., Agostini S., Masini F. \& SAVORELLi A. 2016. - Observations on the postcranial anatomy of Hoplitomeryx (Mammalia, Ruminantia, Hoplitomerycidae) from the Miocene of the Apulia Platform (Italy). Palaeontographica A (Paleozoology, Stratigraphy) 307: 105-147.

MAZZA P. P. A. 2013. - The systematic position of Hoplitomerycidae (Ruminantia) revisited. Geobios 46: 33-42. https://doi. org/10.1016/j.Geobios.2012.10.009

Mennecart B., De Miguel D., Bibi F., Rössner G. E., Métais G., Neenan J. M., Wang S., Schulz G., Müller B. \& CosTEUR L. 2017. - Bony labyrinth morphology clarifies the origin and evolution of deer. Scientific Reports 7: 1-11. https://doi. org/10.1038/s41598-017-12848-9

Meunier K. 1963. - Die Knickungsverhältnisse des Cervidenschädels. Mit Bemerkungen zur Systematik. Zoologischer Anzeiger 172: $184-216$

Monson T. A. \& HLusko L. J. 2018. - The Evolution of Dental Eruption Sequence in Artiodactyls. Journal of Mammalian Evolution 25: 15-26. https://doi.org/10.1007/s10914016-9362-9

OwEN R. 1848. - Description of teeth and portions of jaws of two extinct anthracotherioid quadrupeds (Hyopotamus vectianus and Hyopotamus bovinus) discovered by the Marchioness of Hastings in the Eocene deposits on the N.W. coast of the Isle of Wight. Contrib. to Hist. Br. Foss. Mamm. 7: 30-71. https:// doi.org/10.1144/GSL.JGS.1848.004.01-02.21

Palombo M. R., Kohler M., Moya Sola S. \& Giovinazzo C. 2008. - Brain versus body mass in endemic ruminant artiodactyls: A case studied of Myotragus balearicus and smallest Candiacervus species from Mediterranean Islands. Quaternary International 182: 160-183. https://doi.org/10.1016/j.quaint.2007.08.037

RAdUlESCU C. \& SAMSON P.-M. 1967. - Sur un nouveau cerf mégacérin du Pléistocène moyen de la dépression de Brasov (Roumanie). Geologica Romana 6: 317-344.

Raia P. \& MEIRI S. 2006. - The Island Rule in Large Mammals: Paleontology Meets Ecology. Evolution (N. Y) 60: 1731-1742 https://doi.org/10.1554/05-664.1

ReEse D. S., Belluomini G. \& IKeya M. 1996. - Absolute dates for the Pleistocene fauna of Crete, in REESE D. S. (ed.), Pleistocene and Holocene Fauna of Crete and Its First Settlers. Prehistory Press, Philadelphia: 47-51.

Schilling A.-M., Calderón-Capote M. C. \& Rössner G. E. 2019. - Variability, morphometrics, and co-variation of the os lacrimale in Cervidae. Journal of Morphology 280: 1071-1090. https://doi.org/10.1002/jmor.21002

SCOPOLI G. A. 1777. - Introductio ad historiam naturalem sistens genera lapidum, plantarum et animalium: hactenus detecta, caracteribus essentialibus donata, in tribus divisa, subinde ad leges naturae. Apud Wolfgangum Gerle, Prag, 506 p. https:// doi.org/10.5962/bhl.title.10827

Seo H., Kim J., Seomun H., Hwang J. J., Jeong H. G., Kim J. Y., KIM H. J. \& CHO S. W. 2017. - Eruption of posterior teeth in the maxilla and mandible for age determination of water deer. Archives of Oral Biology 73: 237-242. https://doi.org/10.1016/j. archoralbio.2016.10.020
Severinghaus C. W. 1949. - Tooth Development and Wear as Criteria of Age in White-Tailed Deer. The Journal of Wildlife Management 13: 195-216. https://doi.org/10.2307/3796089

SimONELLI V. 1908. - Mammiferi quaternari dell'Isola di Candia. Memorie della Accademia delle Scienze dell'Istituto di Bologna 4: 456-470.

SimPSON G. G. 1940. — Mammals and land bridges. Journal of the Washington Academy of Sciences 30: 137-163.

Simpson G. G., Roe A. \& LeWontin R. C. 1960. - Quantitative Zoology, Revised Ed. Ed. Harcourt, Brace, New York, 440 p.

SMith B. H. 2000. - Schultz's rule' and the evolution of tooth emergence and replacement patterns in primates and ungulates, in Teaford M. F., Smith M. M. \& Ferguson M. W. J., Development, Function and Evolution of Teeth. Cambridge University Press, Cambridge, New York, Melbourne, Madrid, Cape Town, Singapore, São Paulo: 212-227. http://hdl.handle. net/2027.42/106593

SONDAAR P. Y. 1971. - Paleogeozoography of the Pleistocene mammals from the Aegean. Opera Bot: 30: 65-70.

SondaAR P. Y. \& Boekschoten G. J. 1967. — Quaternary mammals in the south Aegean island arc with notes on other mammals from the coastal regions of the Mediterranean, I/ II. Proceedings of the Koninklijke Nederlandse Akademie van Wetenschappen 70: 556-576.

STARCK D. 1979. - Vergleichende Anatomie der Wirbeltiere aufevolutionsbiologischer Grundlage: Band 2: Das Skelettsystem. SpringerVerlag, Berlin, Heidelberg, 776 p.

Strasser T. F., Murray S. C., van der Geer A., Kolb C. \& RupreCHT L. A. 2018. - Palaeolithic cave art from Crete, Greece. Journal of Archaeological Science: Reports 18: 100-108. https://doi.org/10.1016/j.jasrep.2017.12.041

UNGAR P. S. 2010. - Mammal teeth: origin, evolution, and diversity, 1st ed. John Hopkins University Press, Baltimore, 304 p.

VAN BEMmel A. C. V. 1949. - Revision of the Rusine Deer in the Indo-Australian Archipelago. Treubia 20: 191-262. https://doi. org/10.14203/treubia.v20i2.2625

VAN DER GEER A. A. E. 2005. - Island ruminants and parallel evolution of functional structures. Quaternaire 2: 231-240.

VAN DER GEER A. A. E. 2008. - The effect of insularity on the Eastern Mediterranean early cervoid Hoplitomeryx: The study of the forelimb. Quaternary International 182: 145-159. https:// doi.org/10.1016/j.quaint.2007.09.021

VAN DER GEER A. A. E. 2014. - Systematic revision of the family Hoplitomerycidae Leinders 1984 (Artiodactyla: Cervoidea), with the description of a new genus and four new species. Zootaxa 3847: 1-32. https://doi.org/10.11646/zootaxa.3847.1.1

VAN DER GEER A. A. E. 2018. - Uniformity in variety: Antler morphology and evolution in a predator-free environment. Palaeontologia Electronica 21.1.9A: 1-31. https://doi.org/10.26879/834

VAN DER Geer A. A. E., Dermitzakis M. \& Vos J. De 2006a. Crete Before the Cretans: the Reign of Dwarfs. Pharos 13: 119-130.

van der Geer A. A. E., Dermitzakis M. \& De Vos J. 2006b. Relative growth of the metapodals in a juvenile island deer: Candiacervus (Mammalia, Cervidae) from Pleistocene of Crete. Hellenic Journal of Geoscience 41: 119-125.

VAN DER GeEr A. A. E., De Vos J., Lyras G. A. \& Dermitzakis M. 2006c. - New data on the Pleistocene Cretan deer Candiacervus sp. II (Cervinae, Mammalia). CFS Courier Forschungsinstitut Senckenberg 256: 131-137.

van der Geer A. A. E., Lyras G. A., MacPhee R. D. E., Lomolino M. \& Drinia H. 2014. - Mortality in a Predatorfree Insular Environment: the Dwarf Deer of Crete. American Museum Novitates 3807: 1-26. https://doi.org/10.1206/3807.1

VeitsChegger K. \& SÁNCHEZ-Villagra M. R. 2016. - Tooth Eruption Sequences in Cervids and the Effect of Morphology, Life History, and Phylogeny. The Journal of Mammalian Evolution 23: 251-263. https://doi.org/10.1007/s10914015-9315-8 
VISLOBOKOVA I. A. 2013. - Morphology, taxonomy, and phylogeny of megacerines (Megacerini, Cervidae, Artiodactyla). Paleontological Journal 47: 833-950. https://doi.org/10.1134/S0031030113080017 WegrzYN M. \& SERWATKA S. 1984. - Teeth eruption in the European bison. Acta Theriologica (Warsz) 29: 111-121. https:// doi.org/10.4098/at.arch.84-9
Welker F., Duijm E., van der Gaag K. J., van Geel B., de Knijff P., van Leeuwen J., Mol D., van der Plicht J., Raes N., Reumer J. \& Gravendeel B. 2014. - Analysis of coprolites from the extinct mountain goat Myotragus balearicus. Quaternary Research 81: 106-116. https://doi.org/10.1016/j. yqres.2013.10.006

Submitted on 7 November 2019; accepted on 6 March 2020; published on 8 March 2021. 


\section{APPENDICES}

APPENDIX 1. - Raw data for 41 craniodental measurements taken for eight new specimens of Candiacervus Kuss, 1975. Length measures are given in millimeters and relative lengths in percent, angles are given in degrees. Abbreviation: na, not applicable.

\begin{tabular}{|c|c|c|c|c|c|c|c|c|}
\hline & $\begin{array}{l}\text { SNSB-BSPG } \\
1972 \text { XIX } 1\end{array}$ & $\begin{array}{l}\text { SNSB-BSPG } \\
1972 \text { XIX } 5\end{array}$ & $\begin{array}{l}\text { SNSB-BSPG } \\
1972 \text { XIX } 7\end{array}$ & $\begin{array}{l}\text { SNSB-BSPG } \\
1972 \times 1 X 200\end{array}$ & $\begin{array}{l}\text { SNSB-BSPG } \\
1972 \text { XIX } 201\end{array}$ & $\begin{array}{l}\text { SNSB-BSPG } \\
1972 \times 1 X 202\end{array}$ & $\begin{array}{l}\text { SNSB-BSPG } \\
1972 \text { XIX } 203\end{array}$ & $\begin{array}{l}\text { SNSB-BSPG } \\
1972 \text { XIX } 204\end{array}$ \\
\hline Sex & female & na & male & male & na & female & male & female \\
\hline $\begin{array}{l}\text { Developmental stage } \\
\text { based on dental wear }\end{array}$ & $\begin{array}{l}\text { early-middle } \\
\text { aged adult }\end{array}$ & old adult & na & early adult & old adult & $\begin{array}{l}\text { middle-aged } \\
\text { adult }\end{array}$ & early adult & old adult \\
\hline 1. Basilar length & 195.37 & na & na & na & na & na & na & na \\
\hline 2. Width bizygomatic & 97.79 & na & na & na & na & na & 86.82 & na \\
\hline 3. Skull height & 49.76 & na & na & na & na & 47.15 & 48.26 & 48.73 \\
\hline 4. Width of the occipital & 72.60 & na & na & na & na & 61.00 & 71.17 & 69.40 \\
\hline 5. Orbital width & 28.96 & na & 29.96 & 30.93 & 29.38 & 28.77 & 29.66 & 28.00 \\
\hline 6. Orbital height & 27.47 & na & 31.23 & 27.76 & 29.47 & 26.56 & 28.16 & 29.00 \\
\hline 7. Orbital shape & 0.95 & na & 1.04 & 0.90 & 1.00 & 0.92 & 0.95 & 1.04 \\
\hline 8. Relative orbit size & 0.93 & na & na & na & 0.79 & 0.97 & na & 0.91 \\
\hline 9. Skull flexion & 100.00 & na & na & na & na & 99.80 & 103.00 & 112.00 \\
\hline $\begin{array}{l}\text { 10. Inclination of the } \\
\text { braincase roof relative to } \\
\text { the braincase axis }\end{array}$ & 16.08 & na & na & 18.09 & na & 15.44 & 17.38 & 15.77 \\
\hline 11. Greatest skull width & 111.47 & na & na & 114.00 & na & 109.83 & 109.86 & 112.30 \\
\hline $\begin{array}{l}\text { 13. Greatest width of the } \\
\text { supraorbital groove }\end{array}$ & 10.16 & na & na & 10.45 & 8.55 & 8.72 & 9.59 & 11.38 \\
\hline $\begin{array}{l}\text { 14. Horizontal diameter of the } \\
\text { supraorbital foramen }\end{array}$ & 5.07 & na & na & 5.79 & 5.06 & 4.46 & 5.27 & 5.12 \\
\hline $\begin{array}{l}\text { 15. Proportion of supraorbital } \\
\text { foramen to groove }\end{array}$ & 0.50 & na & na & 0.55 & 0.59 & 0.51 & 0.55 & 0.45 \\
\hline $\begin{array}{l}\text { 16. Length of the foramen } \\
\text { ovale }\end{array}$ & 6.77 & na & na & 6.48 & na & 10.85 & 8.58 & 11.10 \\
\hline $\begin{array}{l}\text { 17. Width of the foramen } \\
\text { ovale }\end{array}$ & 5.02 & na & na & 4.16 & na & 6.28 & 4.12 & 6.84 \\
\hline $\begin{array}{l}\text { 18. Shape of the foramen } \\
\text { ovale }\end{array}$ & 1.35 & na & na & 1.56 & na & 1.73 & 2.08 & 1.62 \\
\hline $\begin{array}{l}\text { 19. Position of the foramen } \\
\text { ovale }\end{array}$ & 35.80 & na & na & 33.00 & na & 29.85 & 35.47 & 34.50 \\
\hline 20. Length of the occipital & 18.25 & na & na & 16.44 & na & 20.32 & 19.71 & 16.81 \\
\hline 21. Length of the parietal & 47.03 & na & na & 45.60 & na & 49.31 & 42.67 & 44.80 \\
\hline 22. Length of the frontal & 58.66 & na & na & 61.63 & na & 66.36 & 64.15 & 57.04 \\
\hline $\begin{array}{l}\text { 24. Inclination of the } \\
\text { tympanic bullae relative to } \\
\text { the meatus acusticus }\end{array}$ & 131.19 & na & na & na & na & 126.25 & 125.91 & 130.54 \\
\hline $\begin{array}{l}\text { 25. Position of the external } \\
\text { meatus acusticus }\end{array}$ & 94.36 & na & na & na & na & 94.19 & 94.06 & 89.32 \\
\hline 26. Orientation of the orbit & 58.92 & na & na & 58.74 & 57.61 & 59.48 & 65.45 & 59.68 \\
\hline 27. Klinorhynchy & 169.63 & na & na & na & na & 171.75 & na & 167.58 \\
\hline 28. Frontal breadth 1 & na & na & na & 54.07 & na & na & 57.36 & na \\
\hline 29. Frontal breadth 2 & na & na & na & 81.44 & na & na & 79.33 & na \\
\hline 30. Facial length & 118.79 & na & na & na & na & na & na & na \\
\hline $\begin{array}{l}\text { 31. Condylobasal length, } \\
\text { CBL }\end{array}$ & 213.3 & na & na & na & na & na & na & na \\
\hline 32. Relative facial length & 55.69 & na & na & na & na & na & na & na \\
\hline 33. Muzzle length & 63.01 & na & na & na & na & na & na & na \\
\hline 34. Relative muzzle length & 29.54 & na & na & na & na & na & na & na \\
\hline 35. Length of the braincase & 64.08 & na & na & 61.03 & na & 65.01 & 61.60 & 62.37 \\
\hline $\begin{array}{l}\text { 36. Greatest width of } \\
\text { braincase }\end{array}$ & 65 & na & na & 62.6 & na & 61.3 & 62.6 & 62.4 \\
\hline $\begin{array}{l}\text { 37. Relative length of } \\
\text { braincase }\end{array}$ & 98.58 & na & na & 97.49 & na & 106.05 & 98.4 & 99.94 \\
\hline $\begin{array}{l}\text { 38. Length of the premolar } \\
\text { row, P2P4 }\end{array}$ & 29.29 & 28.97 & na & na & 27.59 & 26.20 & na & 28.05 \\
\hline $\begin{array}{l}\text { 39. Length of the molar row, } \\
\text { M1M3 }\end{array}$ & 40.43 & 35.84 & na & 42.07 & 33.75 & 40.41 & 42.11 & 37.35 \\
\hline $\begin{array}{l}40 \text { Relationship between } \\
\text { molar and premolar row }\end{array}$ & 0.72 & 0.81 & na & na & 0.82 & 0.65 & na & 0.75 \\
\hline $\begin{array}{l}\text { 41. Length of tooth } \\
\text { row, P2M3 }\end{array}$ & 67.73 & 63.75 & na & na & 62.90 & 67.13 & na & 58.68 \\
\hline
\end{tabular}


- Schilling A.-M. \& Rössner G. E.

APPENDIX 2. - Comparative dataset for the descriptive statistics on dental variables. Data for Mavro Mouri 4c and Gerani 4 are taken from de Vos (1984: table 2), data for Simonelli Cave are taken from Simonelli (1908: 9; specimens II and III). Abbreviations: Sd, standard deviation; CV, coefficient of variation, given in percent; Min, minimum; Max, maximum. All measurements are given in $\mathrm{mm}$.

\begin{tabular}{|c|c|c|c|c|c|c|c|}
\hline & Site & $\mathbf{n}$ & Mean & Sd & CV & Min & Max \\
\hline 39. Length of the premolar row, P2P4 & Mavro Mouri 4c & 7 & 28.89 & 1.98 & 6.85 & 25.1 & 30.8 \\
\hline 40. Length of the molar row, M1M3 & & 5 & 38.6 & 3.47 & 8.98 & 34.8 & 43.4 \\
\hline 42. Length of tooth row, P2M3 & & 2 & 70.90 & 2.4 & 3.38 & 69.2 & 72.6 \\
\hline 39. Length of the premolar row, P2P4 & Gerani 4 & 58 & 25.96 & 1.89 & 7.28 & 22.3 & 31.4 \\
\hline 40. Length of the molar row, M1M3 & & 75 & 37.38 & 2.8 & 7.49 & 31.3 & 43.9 \\
\hline 42. Length of tooth row, P2M3 & & 70 & 62.79 & 3.67 & 5.84 & 53.2 & 71.7 \\
\hline 39. Length of the premolar row, P2P4 & Simonelli Cave & 2 & 30.5 & 1.06 & 3.47 & 29 & 32 \\
\hline 40. Length of the molar row, M1M3 & & 2 & 39 & 1.41 & 3.61 & 37 & 41 \\
\hline 42. Length of tooth row, P2M3 & & 2 & 67.25 & 3.36 & 4.99 & 62.5 & 72 \\
\hline
\end{tabular}

